\title{
THE IMPACT OF TRADE LIBERALIZATION ON HOUSEHOLD WELFARE IN VIETNAM
}

\author{
Ganesh Seshan ${ }^{1}$ \\ World Bank \\ University of Virginia
}

\begin{abstract}
What is the effect of trade liberalization on households in developing countries? To what extent do the poor benefit when local markets are made more accommodative to international trade? I empirically analyze the distributional impact of trade policies on households in a low-income country with a large rural economy where labor markets are imperfect. The methodology proposed in this paper, which can be applied to various types of labor market conditions, relates changes in prices attributed to trade reforms to changes in household welfare, income distribution and poverty using theoretically consistent measures of producer and consumer welfare. I investigate the effects on poverty and income distribution of national and international market integration in Vietnam's rice sector and fertilizer market between 1993 and 1998, a period of ongoing market reforms when the national poverty rate fell sharply from $59 \%$ to $37 \%$. I find that when the effects of opening the rice and fertilizer market are isolated, Vietnam's agricultural trade reforms did not contribute to a significant improvement in overall household welfare or decline in poverty over this period. Nonetheless, the liberalization exercise can explain about half of the reduction in poverty incidence among farm households. The results also show that liberalization did not exacerbate income inequality, but did generate gains for rural households across the distribution, particularly the poor, at the expense of urban households.
\end{abstract}

Keywords: $\quad$ trade liberalization, imperfect labor markets, non-separability, shadow wages, welfare, farm income inequality, rural poverty, Vietnam.

JEL No: $\quad$ F14, F16, O24, Q12

World Bank Policy Research Working Paper 3541, March 2005

The Policy Research Working Paper Series disseminates the findings of work in progress to encourage the exchange of ideas about development issues. An objective of the series is to get the findings out quickly, even if the presentations are less than fully polished. The papers carry the names of the authors and should be cited accordingly. The findings, interpretations, and conclusions expressed in this paper are entirely those of the authors. They do not necessarily represent the view of the World Bank, its Executive Directors, or the countries they represent. Policy Research Working Papers are available online at http://econ.worldbank.org.

I am grateful to John Mclaren, Eric Van Wincoop and John Pepper for their guidance throughout this project. I thank without implicating Sanjay Jain, Quy-Toan Do and seminar participants at the University of Virginia.

${ }^{1}$ World Bank and Department of Economics, University of Virginia, P.O Box 400182, Charlottesville, VA 22904-4182. Email: seshan@virginia.edu. 


\section{Introduction}

How does trade liberalization affect household welfare? Who gains and who loses as national markets are opened to trade? In particular, what happens to poor households when developing countries liberalize their economies? In spite of considerable debate on the impact of trade reforms on living standards, there is limited empirical work examining the distributional effect of trade liberalization in a low-income country with a large rural economy. Prior studies, mainly on middle-income countries, have focused on urban labor markets and only recently on urban poverty ${ }^{2}$. When rural economies are examined, with the exception of a few studies, most confine welfare estimates to first-order responses, ${ }^{3}$ while ignoring labor market repercussions. All of them assume complete labor markets, which is harder to justify in a rural economy where high transaction cost, underemployment and seasonal work are prevailing features. The purpose of this paper is to examine changes to household welfare, inequality and poverty in Vietnam induced by actual price changes attributed to trade liberalization in the rice and fertilizer market between 1993 and 1998, in a setting with imperfect rural labor markets.

Between 1993 and 1998, Vietnam experienced a period of ongoing market and trade reforms which saw real rice prices rising over 30 percent and the real prices of mainly imported chemical fertilizers, a key farm input, declining by 18 percent on average. Rice is the single most important source of income for the majority of Vietnamese as well the main staple in their diet. Benjamin and Brandt (2004) find that most of the increase in real rice prices was due to international and national rice market integration. To a large extent, the increase in domestic rice prices is due to relaxation of a rice export quota, which by 1998 was no longer

\footnotetext{
${ }^{2}$ Looking at a recent survey of trade liberalization in developing countries by Goldberg and Pavcnik (2004), one finds that most studies of trade liberalization episodes look at wage inequality in the manufacturing sector in Latin America. As the authors point out, while this focus may not be a concern in studies of trade reform on urban sectors in middle income countries, only a small share of the population in poorer economics participate in labor markets as wage earners. Recent works on urban poverty are by Porto (2003) on Argentina and Nicita (2004) on Mexico.

3 These first-order responses, popularized by Deaton (1989) are only suited for small price changes. The production response of producers to price changes are considered more significant that the substitution behavior of consumers. Only a few studies have considered second order responses, such as Ravallian and Van De Walle (1991) for Indonesia and Minot and Goletti (1998) for Vietnam. Both studies were ex-ante analysis with hypothetical or simulated price changes. These studies do not consider how rural labor markets are affected.
} 
binding ${ }^{4}$. Internal restrictions on rice trade which prevented rice produced in the south from being traded in the north of Vietnam were also lifted in $1997^{5}$. Import quotas on chemical fertilizers were also relaxed over this interval. Poverty rates fell sharply from 59 percent to 37 percent over this interval, leading some to attribute this remarkable outcome to global integration ${ }^{6}$. Income inequality rose, driven mainly by differences between urban and rural areas $^{7}$. Over 80 percent of Vietnam's population in 1993 resided in rural areas and were engaged primarily in agricultural work, making the analysis of their welfare pertinent in learning about rural poverty. The distinctive feature of this paper is the availability of a household panel dataset that spans a period of agricultural trade reforms in Vietnam between 1993 and 1998. The use of panel data arguably allows for a much better identification of the effects of trade liberalization on household welfare.

The approach used in this study goes beyond existing work in four different dimensions. First, I consider welfare and poverty outcomes among urban and rural households. Second, actual price changes are used instead of simulated or hypothetical changes seen in other studies. As Edmonds and Pavcnik (2002) observed, the degree of price changes varies across regions which implies that geographically dispersed households will be affected differently by trade liberalization ${ }^{8}$. Third, household welfare measures consistent with utility maximizing and profit maximizing behavior are computed as opposed to relying on producer and consumer surplus approximations. These welfare measures include secondorder responses by producers and consumers in reacting to changes in rice and fertilizer prices. Fourth, in analyzing the farm household, I depart from the usual assumption of complete labor markets which allows for separability between household labor demand and supply decisions. Household members face binding constraints in seeking off-farm

\footnotetext{
${ }^{4}$ The export quota on rice was eliminated in 2001.

${ }^{5}$ A major land reform took place in 1993 where tenure security was extended and households were given the right to exchange, transfer, lease and mortgage land. A land titling process was initiated and by 1997, almost half of all land was titled, affecting two-third of households. However, according to Benjamin and Brandt (2004) most of the changes took place towards the end of the period, and probably did not have sufficient time to be reflected in production and output behavior.

${ }^{6}$ Dollar (2004) is the clearest proponent of the view that 'globalizing' countries like Vietnam reaped the benefit of poverty reduction, through the export of rice and labor intensive products such as footwear, without a significant change in income inequality.

7 Several inequality measures lead to the same conclusion. The Gini index rose from 0.329 to 0.352 . The Theil $\mathrm{T}$ measure increased from 0.2 to 0.23 . See Glewwe, et.al (1999) for a discussion on inequality in Vietnam.

8 The price transmission mechanism is likely more important in low-income countries where local markets face high transaction costs and are poorly integrated into the international economy.
} 
employment, due to labor market failures and therefore work intensively on their own farm? This raises the need to account for the implicit value of family labor, which I do. Using market wages will overstate the cost of family labor, thereby understating the welfare estimates.

In terms of methodology, I begin by estimating structural parameters of a multi-output production function using the household panel dataset from which the marginal revenue product or shadow wage of family labor is derived. This approach avoids the need to form prior assumptions about prevailing labor market conditions and includes separability as a special case. A profit function based on the underlying multi-output production function is constructed to evaluate the response of farm profits to changes in output and input prices. In doing so, I also consider the general equilibrium reaction of shadow wages to changes in rice prices. This allows me to isolate the impact of higher producer rice prices and lower fertilizer prices attributed to external liberalization on a farm household's profitability, which is then combined with changes in their consumer welfare, measured using compensating variation. The general nature of this methodology permits its application to non-farm households as well. To my knowledge, this is the first study of the distributional consequences of trade reforms to incorporate an explicit analysis of shadow wages in determining the profitability of farmers in a rural setting with imperfect labor markets.

The results show that rural households across the income distribution benefited from the liberalization exercise, with lower-income rural households gaining proportionally more. The rural poor clearly gained while urban households, particularly the poor, were at a disadvantage with rising rice prices, though their welfare loss was marginal. The gains were more evidently seen in households with large holdings of farmland. Inequality of farm income rose slightly and while I find that agricultural trade reforms can explain nearly half of the decline in poverty among farmers, the impact on the overall poverty rate for Vietnam was modest. This outcome necessitates caution in attributing liberalization in the rice sector and fertilizer as contributing significantly to poverty reduction in Vietnam.

\footnotetext{
${ }^{9}$ See Benjamin (1992) for a fuller discussion on non-separability between labor supply and demand. Jacoby (1993) and Skoufias (1994) develop an approach to determine the implicit wages for households who are not earning wages.
} 
The next section describes the methodology used to measure welfare changes facing Vietnamese households over the reform period. Section 3 discusses the dataset and empirical implementation of the welfare concepts introduced in Section 2. The resulting welfare measures are discussed in Section 4. Section 5 examines the robustness of the results using an alternative price measure and poverty dominance concepts and Section 6 concludes.

\section{Measurement of Welfare Changes}

According to Winters (2002) in his survey of linkages between trade reforms and poverty, trade policies operate primarily via price changes. The direct effect of trade liberalization on households would be through change in prices that reach them. The impact of a price change on household welfare depends on whether the household is a net producer or net consumer of the good or services in question ${ }^{10}$.

An appropriate framework to address welfare changes affecting households in Vietnam, the majority of which are involved in agricultural activity, is to recognize that these households make joint decisions regarding consumption, production and labor allocation. The literature has developed models suited to the study of farm households ${ }^{11}$, which is the primary feature in Vietnam. However, most empirical studies have relied on assuming there are perfectly competitive markets for labor and other inputs and outputs. Family and hired labor are treated as perfect substitutes, there is no disutility from working off farm and there are ample off-farm job opportunities. This allows labor supply and demand decisions to be separable, where a farm household initially decides on how much labor is needed to maximize profits from agriculture without considering its leisure or consumption preferences. Given farm profits, market prices and wages, the farm then decides on how much to consume and

\footnotetext{
10 I do not examine the extent to which price changes at the borders due to trade liberalization are actually transmitted to the household. This would depend on several factors, notably the structure of distribution sector, the way in which government institutions such as marketing organization operate and whether goods are traded at the local, regional, national or international level. A 2003 World Bank study did find that farm-gate prices are 80 percent of border prices for rice and that rice farmers capture as much as 82 percent of the profits from the value chain running from producers to exporters.

${ }^{11}$ See Singh, Squire and Strauss (1986) for a survey of agricultural household models.
} 
how much labor to supply. Under separability the market wage provides an exogenous measure of the value of time for family labor, irrespective of whether they work on or off farm.

Off-farm employment opportunities are limited in Vietnam, in part due to the seasonal nature of work, the communist legacy of self-subsistent farming particularly in the north $^{12}$, the absence of state support for rural enterprises, underdeveloped rural physical infrastructure and lack of access to marketable skills, capital and credit $^{13}$. Among farm households in 1993, only 12.4 percent of the total hours worked by family members is spent earning wages, with the fraction of time spent in the market being higher in the south at 16.6 percent compared to the north at 9.5 percent $^{14}$. Additionally, is unlikely that family labor and hired labor can be treated as perfect substitutes due to transportation and monitoring cost. Only $30 \%$ of farm households hire labor though the southern regions, particularly the Mekong River Delta, employ more casual farm labor than the north.

If labor markets are imperfect, household production and consumption decisions can not be treated as separable, as their labor supply choices are no longer independent of labor demanded on the family farm and vice versa. Instead of the market wage, it is the 'shadow wage' that determines labor supply and demand choices for the farm household. The shadow wage, being the marginal (revenue) product of labor, is further determined within the household and is a function of household preferences, technology and all other fixed input and market prices affecting household choices. This approach avoids the need to make any

\footnotetext{
${ }^{12}$ There are seven agro-economics zones or administrative regions in Vietnam. The north includes the Northern Mountains and Midlands, the Red River Delta and the North Central Coast. The south is made of the South Central Coast, The Central Highlands, the Southeast and the Mekong River Delta. The two most important rice production regions include the Red River Delta (15\% of national paddy output) and the Mekong River Delta (50\% of national output).

${ }^{13}$ See Van de Walle and Cratty (2003) for a discussion on constraints facing the non-farm market economy.

1440 percent of farm households in 1993 have members who work in the market, with the South providing proportionally more market opportunities, where 48.5 have market work compared to 34 percent in the North. A similar picture emerges with hired in labor where on average only 30 percent of farmers in Vietnam employ casual labor. The South employs far more with 54 percent of farmers hiring in labor, whereas only 14.1 percent of North farmers hire agricultural workers. While there is an active labor market, more so in the South where households both hire and sell labor, slack season and underemployment are predominant features of rural labor markets. The small fraction of time spent by farm households working in the market provides some evidence in favor of this view for Vietnam.
} 
assumptions about the state of labor markets, and nests separability of labor decisions as a special case.

To motivate the empirical work, I use a stylized farm household model drawing on work by Benjamin (1992) and Jacoby (1993). Assume that households consume two commodities: an agriculture good, $c$ valued at price $p$ and leisure, $l$. Household members allocate their time endowment, $T$ between leisure, $l$, working on farm, $z^{F}$ and market work, $m$. The market wage for off-farm work, $w^{M}(p)$ is a function of the price of the agriculture good. The farm household uses both family and hired labor $z^{H}$, no longer considered as perfect substitutes and land, $v^{D}$, a fixed input to produce output, $q$ which is sold at price $p$. The concave production technology is described by $q\left(z^{F}, z^{H} ; v^{D}, \boldsymbol{\Phi}\right)$ where $\boldsymbol{\Phi}$ is a vector of household characteristics such managerial ability and years of experience, as well as weather and soil conditions affecting production. Hired workers are also paid the market wage, $w^{M}$. With these specifications, the households choose $c, z^{F}, m$ and $z^{H}$ so as to

$$
\begin{gathered}
p c=p q\left(z^{F}, z^{H} ; v^{D}, \boldsymbol{\Phi}\right)+w^{M}(p)\left(m-z^{H}\right)+g \\
l+z^{F}+m=T \\
0 \leq m \leq H
\end{gathered}
$$

where $\boldsymbol{B}$ is a vector of individual and household characteristics affecting preferences, $g$ is endowment income and $H$ is the maximum number of hours that a household may work off its farm.

The first-order condition for this problem has each household equating its marginal rate of substitution between leisure and consumption, or shadow wage, either to their market wage or to their marginal product of labor. If household members engage in market work and 
the work ration is not binding, their shadow wage will equal the market wage received in the market, i.e.

$$
\frac{u_{l}}{u_{c}} \equiv w^{S}=w^{M}, \text { where } w^{S} \text { is defined as the shadow wage rate. }
$$

Household members supply labor on their farm until their marginal products are equal to the market wage. Beyond this, their marginal revenue product will decline due to diminishing returns and they will instead resort to market work. Alternatively, if the household chooses not to hire out labor to the market but prefers to work on the family farm, then the shadow wage, which is given by the marginal revenue product of family labor, must exceed the market wage,

$$
w^{S}\left(p ; v^{D}, \boldsymbol{\Phi}, \boldsymbol{B}\right)=p q_{z^{F}}>w^{M} .
$$

However, if household members want to work in the market, and the desired labor supply exceeds the sum of available off-farm work, measured by $H$ and on-farm labor demand, then the family will work on its own farm for additional employment. The shadow wage, being a function of exogenous price, $p$ will now be lower than the market wage,

$$
w^{S}\left(p ; v^{D}, \boldsymbol{\Phi}, \boldsymbol{B}\right)=p q_{z^{F}} \leq w^{M} \text {, when } m=H \text { is binding. }
$$

In both the previous cases, preferences for leisure enter into the farm labor demand decision, and labor supply is determined by the agriculture technology. The decision not to participate in the labor market or the inability to find sufficient formal work leads to a household budget constraint that is non-linear in hours worked. As Jacoby (1993) and Skoufias (1994) stated, the gradient of the budget constraint at the optimum is just the shadow wage where $w^{S}=p q_{z^{F}}$. Each household will have its shadow wage level determined uniquely by the data. At this point, the constraint is linear. The 'full income' of the household at the optimum is given by 


$$
\begin{gathered}
y=w^{S} T+\pi\left(p, w^{S}(p), w^{M}(p) ; v, \boldsymbol{\Phi}\right)+g \text { where } \\
\pi=\operatorname{Max}_{z^{F}, z^{H}} p q\left(z^{F}, z^{H} ; v^{D}, \boldsymbol{\Phi}\right)-w^{M}(p) z^{H}-w^{S}(p) z^{F},
\end{gathered}
$$

where $\pi$ is the "shadow" farm profit, with the opportunity cost of family labor accounted for. The budget constraint evaluated at the optimum can be rewritten as

$$
p c+w^{S} l=y,
$$

where the expression on the left-hand side is the value of total household expenditure on goods and leisure and the right-hand side expression, $y$ is the 'full income'. The shadow wage is used to value leisure and time endowment. The budget constraint states that the expenditure on all goods including leisure cannot exceed the full income, which is the sum of farm 'shadow' profits, value of time endowment and non-labor, non-farm income. The utility function in ( 1) can now be maximized subject to ( 7 ) yielding the same first-order conditions discussed earlier.

Evaluating the change in full income in response to changes in the output price involves estimating the response of profit and the change in the value of time, as the shadow wage is affected by the output price changes. The value of time is a product of the shadow wage and total time endowment, $T$. Once shadow wages are accounted for, households can be treated as price takers, using shadow wages as an input price.

\subsection{Welfare Measure}

The welfare impact of price and income changes on households can be measured in monetary terms by using money metric indirect utility measures. Using a set of reference prices, it can be determined how well or worse off households are, moving from their initial utility level to the new or post-reform utility level in response to price changes, while accounting for their factor shadow wage response to price changes. If the post-reform price level is used, the measure of net welfare gain, $W G$ is given by the difference between two expenditure functions valued at the new price level. 


$$
\begin{aligned}
W G & =E\left(\boldsymbol{p}_{1}, u_{1}\right)-E\left(\boldsymbol{p}_{1}, u_{0}\right) \\
& =y_{1}\left(\boldsymbol{p}_{1}\right)-E\left(\boldsymbol{p}_{1}, u_{0}\right) \\
& =\left[y_{1}\left(\boldsymbol{p}_{1}\right)-y_{0}\left(\boldsymbol{p}_{0}\right)\right]+y_{0}\left(\boldsymbol{p}_{0}\right)-E\left(\boldsymbol{p}_{1}, u_{0}\right) \\
& =\Delta y-\left[E\left(\boldsymbol{p}_{1}, u_{0}\right)-E\left(\boldsymbol{p}_{\boldsymbol{0}}, u_{0}\right)\right] \\
& =\Delta y-C V
\end{aligned}
$$

where the term $E(\boldsymbol{p}, u)$ gives the minimum cost of achieving the utility level $u_{h}$ for the set of prices denoted by the vector $\boldsymbol{p}$ facing the household and $C V$ is the familiar indirect utility measure of compensating variation, which is the amount of money which the household would need to be given at the new set of prices in order to attain their pre-reform initial level of utility. Subscripts refer to before (0) and after (1) prices changes which corresponds in this study to 1993 and 1998 respectively. The change in net welfare or real income is the change in full income less compensating variation. A positive sign indicates an improvement in welfare and vice-versa. Using a general form of the full income term in equation (6) and dividing by initial income, the expression can be rewritten to be,

$$
\begin{aligned}
W G / y_{0} & =\left(T\left(w^{S}\left(\boldsymbol{p}_{1}\right)-w^{S}\left(\boldsymbol{p}_{\boldsymbol{0}}\right)\right)+\pi\left(\boldsymbol{p}_{1}, \boldsymbol{w}\left(\boldsymbol{p}_{\boldsymbol{1}}\right) ; \boldsymbol{v}_{\boldsymbol{0}}\right)-\pi\left(\boldsymbol{p}_{0}, \boldsymbol{w}\left(\boldsymbol{p}_{\boldsymbol{0}}\right) ; \boldsymbol{v}_{\boldsymbol{0}}\right)-C V\right) / y_{0} \\
& =(\underbrace{T \Delta w^{S}(\boldsymbol{p})}_{\Delta \text { in value of endowed time }}+\underbrace{\Delta \pi(\boldsymbol{p}, \boldsymbol{w}(\boldsymbol{p}) ; \boldsymbol{v})}_{\Delta \text { in proftiability }}-\underbrace{C V\left(\boldsymbol{p}_{\boldsymbol{1}}, \boldsymbol{p}_{\boldsymbol{0}}, u_{0}\right)}_{\text {compensating variation }}) / y_{0}
\end{aligned}
$$

Therefore the welfare gain to farm households is the change in the sum of the value of time endowment and shadow profits in response to price changes less compensating variation. The remaining subsections look at each of these components in greater detail with attention paid to the nature of data for Vietnam. Attention will be restricted at the household level to exogenous changes in consumer and producer price of rice (or paddy) directly and indirectly through the latter's effect on endogenous shadow wages and on exogenous changes in chemical fertilizer price. 


\subsubsection{Time Endowment}

To examine the change in the value of time endowment for a farm household, the shadow wage is required, which is derived from an underlying production function. As Vietnamese farmers are observed producing multiple crops, I follow Strauss (1984) in defining an implicit production function of the form $F(\boldsymbol{q}, \boldsymbol{z} ; \boldsymbol{v})$ where $\boldsymbol{q}$ is a vector of outputs, $\boldsymbol{z}$ is a vector of variable inputs and $\boldsymbol{v}$ is a vector of quasi-fixed inputs. This is justified by the parsimony in parameters that is achieved in contrast to assuming separate production functions for each output. In addition, the VLSS datasets do not adequately break down the input use by crops ${ }^{15}$.

Among the possible functional forms to use for inputs is the Cobb-Douglas (CD) ${ }^{16}$. For outputs, the counterpart of the constant elasticity of substitution is the constant elasticity of transformation (CET) introduced by Powell and Gruen (1968). This takes the form $H(X)=\left(\sum \gamma_{i} X_{i}^{\sigma}\right)^{1 / \sigma}$ where $\gamma_{i}>0$ and $\sigma>1$ to insure convexity. The constant elasticity of transformation between outputs is $1 /(\sigma-1)$. The $\mathrm{CD}$ function for inputs can be written as,

$$
Q_{h t}(\boldsymbol{z}, \boldsymbol{v}) \equiv\left(\sum_{i=1}^{I} \gamma_{i h} q_{i h}^{\sigma}\right)^{1 / \sigma}=\kappa \prod_{j=1}^{J} z_{j h t}^{\alpha_{j}} \prod_{k=1}^{K} v_{k h t}^{\theta_{k}} \exp \left(\vartheta_{h t}\right), \text { and therefore, }
$$

where $Q_{h t}$ represent an index of agricultural outputs produced by farm household $h$ in year $t, \kappa$ is a term capturing productivity, $z_{j h t}$ is the quantity of variable input $j$ used by farmer $h$ in year $t, v_{k h t}$ is the quantity of quasi-fixed input $k$ and the disturbance term is given by $\vartheta$. The production system is normalized such that $\sum \gamma_{i}=1$. By maximizing output revenue with respect with one unit of the output index, $\left(Q_{h}=1\right)$, it can be shown that output shares,

\footnotetext{
${ }^{15}$ For this study, the possible outputs are paddy, other food crops, annual crops, perennial crops and fruit crops. There are five variables inputs, namely family labor, hired labor, organizer fertilizer, chemical fertilizer and insecticides. Fixed inputs are cultivated land and capital.

16 A more flexible form was attempted in the empirical stage with unsatisfactory results.
} 


$$
\begin{aligned}
\gamma_{i} & =\left(p_{i} q_{i}\right)^{1-\sigma} p_{i}^{\sigma} / \sum_{j}\left(p_{j} q_{j}\right)^{1-\sigma} p_{j}^{\sigma} \text { and the producer price index, } \\
P & =\left(\sum_{i=i}^{I} \gamma_{i}^{-1 /(\sigma-1)} p_{i}^{\sigma /(\sigma-1)}\right)^{(\sigma-1) / \sigma} \text { with output price of commodity } i \text { given by } p_{i} .
\end{aligned}
$$

The marginal product of family labor or shadow wage, $w^{S}$, suppressing the disturbance term and subscripts for household and time, can then be derived as:

$$
w^{S}(\boldsymbol{p}, \boldsymbol{w}(\boldsymbol{p}) ; \boldsymbol{v}, \boldsymbol{\Phi}, \boldsymbol{B})=\frac{\alpha^{F} P Q}{z^{F}},
$$

where $\alpha^{F}$ is share of family labor in used in production of all outputs, which will be empirically estimated and $z^{F}$ is the total annual hours of own-farm labor by family members observed in the data. Note that the shadow wage is a function of exogenous output prices, input prices - some of which respond endogenously to changes in the output price such as the agricultural market wage, the production technology and household characteristics.

Since I'm interested in isolating the effects of changes in paddy price on the shadow wage, a reduced form Mincerian type regression for the shadow wage equation will be estimated which will contain crop output and input prices except for market wage for casual labor (which is a function of output prices) and include other farm and household characteristics. If done in logs, the elasticity of the shadow wage with respect to the producer price of rice, $p_{r}^{p}$ is given by $\delta_{s r}=\partial \ln w^{S} / \partial \ln p_{r}^{p}$, where $\delta_{s r}$ is the estimated coefficient in front of $\log$ paddy price $^{17}$. A rise in the price of paddy is expected to raise the demand schedule for family labor, therefore the shadow wage will have to rise to re-equate household labor supply with demand ${ }^{18}$.

\footnotetext{
17 This elasticity incorporates the endogenous response of market wages to the price of rice.

${ }^{18}$ It is possible there will be an offsetting negative effect on the shadow wage due to higher market wages for hired labor in reaction to increased rice prices. Farmers may substitute away from more costly hired labor and into family labor, lowering their marginal product. This effect if any, is less of a concern in Northern Vietnam due to the insignificant presence of hired labor on household's farms. However, the more prominent role of hired labor in the South may lead to shadow wages falling in response to higher paddy prices.
} 
Having obtained the elasticity of shadow wage to rice paddy price, holding all other variables constant, the change in the value of time endowment facing the household can be given by,

$$
\begin{aligned}
T \Delta w^{*} & =T\left(w^{*}\left(p_{1 r}\right)-w^{*}\left(p_{o r}\right)\right) \\
& =T\left(\left(\frac{p_{1 r}^{p}}{p_{0 r}^{p}}\right)^{\delta_{r}}-1\right) w_{0}^{*}
\end{aligned}
$$

\subsubsection{Shadow Profit}

Once the shadow wage is determined, it can be treated as the input price of self-employed farm family labor. The maximized variable profit function at the household level is therefore,

$$
\begin{aligned}
& \max \pi=\sum_{i=1}^{I} p_{i} q_{i}-\sum_{j=1}^{J} w_{j} z_{j} \text { subject to } \\
& \left(\sum_{i=1}^{I} \gamma_{i} q_{i}^{\sigma}\right)^{1 / \sigma} \leq \prod_{j=1}^{J} z_{j h t}^{\alpha_{j}} \prod_{k=1}^{K} v_{k h t}^{\theta_{k}}
\end{aligned}
$$

with respect to $q_{i}$ 's and variable inputs $z_{j}$ 's. Input prices are denoted by $w_{j}$ and include the shadow wage rate, $w^{S}$.

The profit maximizing output supply and factor demand equation are given by:

$$
q_{i}=\left(\gamma_{i}^{-1} p_{i}\right)^{1 /(\sigma-1)} A W P^{\sigma a-1 /(\sigma-1)(1-a)} V, \forall i
$$

where,

$$
z_{j}=\alpha_{j} A w_{j}^{-1} W P^{1 /(1-a)} V, \forall j
$$


$a=\sum_{j=1}^{J} \alpha_{j}<1, A=\left(\prod_{j=1}^{J} \alpha_{j}^{\alpha_{j}}\right)^{1 / 1-a)}, W=\left(\prod_{j=1}^{J} w_{j}^{-\alpha_{j}}\right)^{1 /(1-a)}$ and $V=\left(\kappa \prod_{k=1}^{K} v_{k h t}^{\theta_{k}}\right)^{1 /(1-a)}$.

In general, with $j$ number of variable input $z_{j h t}$ and $k$ number of quasi-fixed inputs, $v_{h t}$, the maximized profit function takes the expression:

$$
\pi(\boldsymbol{p}, \boldsymbol{w} ; \boldsymbol{v})=(1-a) A W P^{1 /(1-a)} V
$$

To get at the change in shadow profits, I first determine the percentage change in household's farm profits, $\tilde{\pi}$ in response to an exogenous change in the rice paddy price and chemical fertilizer price while taking into account the indirect impact on the shadow wage and market wage for hired labor,

$\tilde{\pi} \equiv \frac{\Delta \pi}{\pi_{0}}=\frac{\pi\left(p_{1 r}, w^{*}\left(p_{1 r}\right), w^{M}\left(p_{1 r}\right), w_{1}^{c}, \boldsymbol{\rho}_{0}, \boldsymbol{\omega}_{0} ; \boldsymbol{v}_{o}\right)-\pi\left(p_{0 r}, w^{*}\left(p_{0 r}\right), w^{M}\left(p_{0 r}\right), w_{0}^{c}, \boldsymbol{\rho}_{0}, \boldsymbol{\omega}_{0} ; \boldsymbol{v}_{o}\right)}{\pi_{0}}$

$$
\tilde{\pi}=\left[\left(\frac{p_{1 r}}{p_{o r}}\right)^{-\alpha^{F} \delta_{s r}}\left(\frac{p_{1 r}}{p_{0 r}}\right)^{-\alpha^{H L} \delta_{m r}}\left(\frac{w_{1}^{c}}{w_{o}^{c}}\right)^{-\alpha^{c}}\left(\frac{P\left(p_{1 r}\right)}{P\left(p_{o r}\right)}\right)\right]^{1 / 1-a}-1,
$$

where $a=\sum \alpha_{j}$ is the sum of variable input shares in the production technology, $w^{c}$ is the price of chemical fertilizer, $\delta_{r}$ is the elasticity of shadow wages with respect to rice paddy price, $\delta_{m r}$ is the elasticity of market wages for hired labor with respect to paddy price ${ }^{19}$, and $\alpha^{F}, \alpha^{H L}$ together with $\alpha^{C}$ are parameters for family labor, hired labor and chemical fertilizer shares respectively in the production function. Lastly, $\boldsymbol{\rho}_{0}$ are initial output prices of crops other than rice paddy and similarly, $\omega_{0}$ are initial input prices other than chemical

\footnotetext{
${ }^{19}$ In preliminary work, attempts to estimate a reduce form agriculture market wage equation at the commune level as a function of crop prices and other control variables led to insignificant results. This is likely due to the small sample size as markets are assumed to clear at the commune level. For future work, I intend to explore this impact at the individual level instead.
} 
fertilizer and the shadow wage rate. Recall that the subscripts (0) and (1) refer to 1993 and 1998 prices respectively. The corresponding change in profit levels is then given by $\Delta \pi=(1+\tilde{\pi}) \pi_{0}$ where $\pi_{0}$ is the level of variable profits in 1993 , derived by subtracting variable cost from the value of production.

\subsubsection{Compensating Variation}

For the compensating variation term in equation (9), I follow Minot and Goletti $(1998,2000)$ in taking a second order Taylor expansion of an expenditure function with respect to consumer rice price, $p_{r}^{c}$ which after dividing through with initial income, $y_{0}$ gives,

$$
\frac{C V}{y_{o}} \cong C R_{r} \frac{\Delta p_{r}^{c}}{p_{o r}^{c}}+\frac{1}{2} C R_{r} \eta_{r r}^{H}\left(\frac{\Delta p_{r}^{c}}{p_{o r}^{c}}\right)^{2},
$$

where $C R_{r}=p_{0 r} x_{0 r} / y_{0}$ is the value of rice consumption as a proportion of initial household income (expenditure), $\Delta p_{r}^{c}$ denotes $p_{1 r}^{c}-p_{o r}^{c}$, the change in consumer rice price from period 0 to period 1 and the own-price compensated Hicksian elasticity of rice demand is given by $\eta_{r r}^{H}$, which can be computed using the elasticity form of the Slutsky equation, $\eta_{r r}^{H}=\eta_{r r}^{M}+C R{ }_{r} \eta_{r y}^{M}$ where $\eta_{r r}^{M}$ is the uncompensated or Marshallian price elasticity of demand for rice while $\eta_{r y}^{M}$ is the corresponding income elasticity.

\section{Empirical Analysis}

The empirical work for this paper relies on the Vietnam Living Standards Survey dataset (VLSS) for 1993 and for 1998 which forms a 4,300 household panel data ${ }^{20}$, covering

\footnotetext{
${ }^{20}$ A total of 4800 households were surveyed in 1993 while 6000 households were surveyed in 1998 of which 4300 were the same households from 1993. No sampling weights were needed for 1993 since it was considered a representative sample unlike in 1998 where rural households were over sampled.
} 
150 communes and spanning the period of export rice quota change. Both household surveys include detailed questions on household composition, the labor activities of adults and children, education, expenditure, land holdings and agricultural activities.

Unlike most household surveys in developing countries, the Vietnamese Living Standard Surveys also include a community price questionnaire. The VLSS 1993 dataset had 120 rural and 30 urban communes which mostly carried over to the 1998 survey $^{21}$. In each commune where households were surveyed, price data were collected on a variety of mainly food and household items ${ }^{22}$.

According to Justino and Litchfield (2002), commune prices (i.e. prices recorded in the community price questionnaire) should more accurately reflect prices faced by households as communes usually have a single market where most households purchase similar goods at the same prices. For these reasons, the empirical results in this paper will use commune rice prices taken from the community price questionnaires as the price measure. As a check of robustness, the findings will be contrasted with results obtained from the use of median rice unit values measured at the commune level.

Table 1 presents the percentage change in consumer and producer rice price as well as chemical fertilizer price between 1993 and 1998 for Vietnam and after deflating by the monthly price index with January 1998 as the base. Rice prices were taken from the community price questionnaire. Due to incomplete data for fertilizer prices, I used unit values derived at the commune level to create a composite fertilizer price index from the household surveys. There are noticeable regional variations in the degree of change observed. Northern Vietnam saw both producer and consumer prices rising relatively less compared to the south. This is probably due to the fact that paddy and rice prices were comparatively much higher in the north in 1993 due to an overall rice-deficit position and that market integration over this

\footnotetext{
${ }^{21}$ In total, there were approximately 10,000 communes in Vietnam in 1993, each with an average population of 6500 .

${ }^{22}$ In the absence of price data, welfare studies for developing countries rely on computing unit values, which are 'prices' derived by dividing expenditure or revenue by quantities bought or sold. The usual concern raised with unit values is that they are choice variables and are affected by problems of quality ${ }^{22}$ and are also likely to measured with error. However, Deaton and Zaidi (2002) suggest that unit values may provide good price information especially when averaged over households in a cluster, or commune in the case of Vietnam.
} 
period has caused a convergence in paddy prices $^{23}$. Chemical fertilizer prices, fell on average by 18.3 percent, declining relatively more in the North.

The following sub-sections elaborate on the empirical approach to account for the consumption and relevant farm production components of the Vietnamese household.

\subsection{Consumer Welfare Estimates}

On the consumer side, the approximate second order compensating variation term as a fraction of initial income, resulting from changes in deflated consumer rice price between 1993 and 1998 is computed using equation ( 18) with price and income elasticities of rice demand taken from Minot and Goletti (1997). These uncompensated, consumption-weighted averages of regional elasticities are shown in the first two columns of Table $2^{24}$. Returning to Table 1, the first column provides the change in deflated consumer rice prices over the 5 year period for the seven regions using commune prices taken from the VLSS commune level price questionnaires. On average, consumer rice prices went up by 31.2 percent for Vietnam with the highest increase of 42.2 in the Central Highlands and the lowest rise of 17.7 percent in the Northern Uplands.

The resulting compensating variation term is presented in Table 3. The burden of higher consumer rice prices fell mainly on rural households and on the poorest ( $1^{\text {st }}$ quartile) of households. Curiously, the Northern Uplands and Mekong River Delta (MRD) experienced similar decreases in welfare despite prices rising by twice as much in the MRD (36.5 percent compared to 17.7 percent). The Northern Uplands is the poorest region in Vietnam while the MRD has the second largest per-capita income after the South East region. This translates into higher rice budget shares for the population residing in the Northern mountains compared to the MRD, so why were their losses proportionally low? It appears that though compensated price elasticity of rice demand is lower in the North perhaps due to the lack of

\footnotetext{
23 The ratio of real paddy or producer farm-gate prices using commune prices between north and south Vietnam was 0.88 in 1993 and it rose to 0.98 in 1998.

${ }^{24}$ Consumer demand for rice is more price sensitive in the south compared to the north. Lower incomes in the north, and therefore a larger share of northern household food budget allocated to rice appears to contribute to larger income elasticities of rice demand relative to the south.
} 
close substitutes, the relatively smaller increase in rice prices of 17.7 percent help reduce the welfare cost to households in the Northern mountains despite allocating 33.7 percent of their total expenditure to rice consumption. In the Mekong Delta by contrast, a combination of higher compensating price elasticity, which allowed households to substitute out of rice more easily, and higher per capita income, which kept the share of rice budget low at 22.2 percent, contributed to relatively lower welfare loss.

Figure 1 shows a nonparametric ${ }^{25}$ regression of the compensating variation as fraction of initial income in 1993 against per capita expenditure in 1993. The two vertical lines denote the 25 and 75 percentile of the per capita expenditure distribution. The downward sloping schedules further reinforce the findings in Table 3 where lower income groups are seen bearing the burden of higher consumer rice prices.

\subsection{Production Function Estimation and Household's Shadow Wage Rate}

As modeled in Section 2, the lack of off-farm employment opportunities implies that the implicit cost of family labor on the farm cannot be evaluated at the market wage rate. Since their internal wages are unobserved, the initial step in the empirical analysis of production behavior is to obtain estimates of the shadow wages or marginal productivity of family labor. This is achieved by first estimating a CET-CD production function described by equation ( 10). Taking logs, the production function to be estimated is given by,

$$
\ln Q_{h t}=\ln \phi+\sum_{j=1}^{5} \alpha_{j} \ln z_{j h t}+\sum_{k=1}^{2} \theta_{k} \ln v_{k h t}+\sum_{m=1}^{M} v_{m} D_{m}+\sum_{n=1}^{N} \delta_{n} X_{n h}+\vartheta_{h t},
$$

where $Q_{h t}$ represents an index of $j$ agricultural outputs produced by farm household $h$ in year $t$ with $Q_{h t}=\left(\sum_{i=1}^{I} \gamma_{i h} q_{i h}^{\sigma}\right)^{1 / \sigma}, z_{j h t}$ is the quantity of variable input $j$ used by farmer $h$ in year $t, v_{k h t}$ is the quantity of quasi-fixed input $k$. I include additional controls where $\boldsymbol{D}$ is a vector of location dummies and topographic variables representing commune-specific

${ }^{25}$ All non-parametric regressions in this study use a bi-weight kernel density estimator with a bandwidth of 0.6. Weights for the bandwidth take on an inverted U-shape that declines to zero at the band's edges. See Deaton (1997) for an exposition of non-parametric techniques. 
characteristics, which affect output such as temperature and topology but are unobservable by an econometrician. Also added is a vector of household head's characteristics, $\boldsymbol{X}$ in order to capture managerial effort. The disturbance term is given by $\vartheta$. Equation (19) is non-linear in the parameter space of the dependent variable. However, if a suitable value for $\sigma$ is chosen, the output share value $\gamma_{i}=\left(p_{i} q_{i}\right)^{1-\sigma} p_{i}^{\sigma} / \sum_{i}\left(p_{i} q_{i}\right)^{1-\sigma} p_{i}^{\sigma}$ can be obtained and the farmer's output index, $Q_{h t}$ can be constructed.

A common concern with estimating agriculture production functions is the presence of simultaneity bias that may arise if random influence on output causes farmers to vary the level of inputs. These shocks are unobserved or unmeasured by the econometrician. One example of a shock is that an anticipated drought may cause a farmer to use less labor for harvesting. In this case $z$ and $\vartheta$ are correlated thereby violating a condition for consistent estimation using OLS. However, shocks such as unusual weather conditions or pests attacks which are unanticipated by the farmer can be assumed to be independent of largely predetermined inputs such as land, and hence uncorrelated. Other influences include timeinvariant farmer's ability and soil quality, which again will cause inputs to be correlated with the error term. The availability of panel data may partially control for the endogeneity of inputs if it is assumed that the disturbance term is composed of three main sources of variation, that is:

$$
\vartheta_{h t}=\mu_{h}+\tau_{t}+\varepsilon_{h t} .
$$

The term $\mu_{h}$ is the farmer's fixed effect capturing time-invariant farmer specific heterogeneity such as managerial ability or soil characteristics, $\tau_{t}$ is a year effect common across all farmers in a given year ${ }^{26}$ and $\varepsilon_{h t}$ is a an error introduced by omitted time-varying variables, measurement, functional form misspecification ${ }^{27}$, data collection and computational

\footnotetext{
${ }^{26}$ In Vietnam, this would help capture the possible incentive effect from increased land tenure security with the passage of the 1993 land law.

27 This would include unmeasured capital components, unmeasured effort variables, input quality such as land, labor and capital and higher order terms of inputs.
} 
procedures. It is assumed that $\varepsilon_{h t}$ has zero mean and constant variance, is uncorrelated over time and with all included regressors. Given these assumptions and after including a time dummy to control for the year effect $\tau_{t}$ the choice of estimator for the production function is determined by the specification of the $\mu_{h}$ term.

\section{Data}

This section describes data used to estimate the production function specified in equation (19). Observations are based on a panel of 3205 farm households over two years, 1993 and $1998^{28}$. The output index consists of five commodity groups, namely paddy, other food crops, annual crops, perennial crops and fruit crops. The five variable inputs included in vector $\boldsymbol{z}_{j h t}$ are annual hours of adult equivalent ${ }^{29}$ family labor, annual hours of hired labor, and annual amount in kilograms of chemical fertilizers, organizer fertilizer and insecticides used. Fixed inputs are cultivated land and capital stock. Additional controls for management input are dummies for households with female heads, years of farm experience and education level of the household head. This assumes that the household head is the primary decision maker on the family farm.

To construct the farm output index, a producer price for each commodity group is needed. With the exception of paddy price that is taken from the commune price questionnaire, the remaining price indices are constructed at the commune level by first deriving the unit value ${ }^{30}$ of an item in a group by using commune farm gate sales revenue and total quantity sold. Then each price or unit value of an item in a commodity group is weighted by the total regional sales revenues for that item to form the commodity group price index. When communes do not produce a particular crop, its price is imputed using the average

\footnotetext{
28 There were 3748 agriculture households in 1993, of which 3365 cultivated rice. In 1998, there were 4207 farm households of which 3504 had rice cultivation.

${ }^{29}$ Instead of relying on calorie intakes which the literature usually does, the total (male) adult equivalent hours is instead created by scaling hours worked by female adults, children between the ages of 6 and 15 and elders above the age of 64 using commune level agricultural market wage ratios. The ratio of adult female to male wage was 0.85 , child to adult male wage was 0.65 and elder to adult male wage was 0.5 . These ratios were surprisingly consistently across both years.

30 With the exception of paddy prices which is used in the empirical work, the community price questionnaire did not have price data for most of the crops produced.
} 
regional value in which that commune is located and weighted using regional sales value. The value of $\sigma$ is set at 1.1 to minimize the root mean squared error term. ${ }^{31}$

Land is measured as the total area harvested ${ }^{32}$. For capital stock, the total market value of the market value of draft animals, tools, machinery and farm equipment was deflated by the monthly commune level consumer price index with January 1998 as the base month. Numerous empirical studies on the agriculture market point to the need to adequately control for land quality, whereas neglecting it may lead to omitted variable bias in the regressions. Though the VLSS data does not provide measures of soil quality and rainfall, the surveys have categories for land quality and measures for area irrigated ${ }^{33}$. To address unobserved heterogeneity across communes, all regression specifications include commune level dummies.

Given the nature of agriculture production, the role of weather or natural shocks is expected to play an important role. Though rainfall data are absent, the community questionnaire has information on natural disasters that led to crop losses such as floods, pests, drought, typhoons and other factors. Variables that measure the number of times these events led to over 10\% crop losses during the year are considered together with a dry season dummy ${ }^{34}$. Additional inputs that may contribute to raising productivity are also included such as the real value of government services for land preparation, irrigation, plant protection and land protection and the real value of private services, which cover renting animals, renting equipment/machinery, maintenance and repair, gasoline and electricity.

All independent variables in the regression are in logarithmic form with the exception of farm experience, measures of natural shocks and location dummies. In the presence of

\footnotetext{
31 The variables share estimates using the CET output index with $\sigma=1.1$ were similar to those obtained using real total output as the dependent variable in the production regression. I also intend to estimate the value of $\sigma$ using non-linear techniques in future work.

32 This is based on the assumption that farm size is a quasi-fixed input. This can be justified by incomplete or non-existent land markets though farmers can rent or sharecrop land even in the absence of land sales. However, rental markets are thin in Vietnam. Reforms to land laws in 1993, which was initiated after the 1993 survey, permitted farmers to hold land under long-term contracts. Even after 5 years, only 15\% of farmers rented-in or sharecropped land in 1998, hence it is not unreasonable to view farm size as fixed.

${ }^{33}$ In addition to using fixed effects to control for unobserved land quality, a number of interaction variables using fraction of area irrigated and percentage of good and poor quality land ${ }^{33}$ are used in an attempt to capture variation in land quality across farms.

34 The dry season for Vietnam is from December to April.
} 
inputs with zero values, the logarithmic transformation was carried out by adding one to all the inputs except family adult equivalent labor, which is always positive, by construction of the sample.

\section{Results}

Table 4 presents the OLS, random effects and fixed effects estimates of the coefficient of the production function. The results are similar across all three specifications. Yet, the presence of unobservable household characteristics and land quality render the random or fixed effect specification more appropriate. The Hausman test which is a test to determine a consistent estimator firmly rejected the random-effects specification in favor of the fixedeffect estimation ${ }^{35}$. This suggests that the fixed-effects specification is preferred as it controls for unobservable farmer specific effects that are correlated with the observed inputs.

The coefficients for hired labor, chemical and organic fertilizer, insecticide as well as area cultivated and capital stock are significant across all specifications at the 5 percent level. Poor quality land negatively affects output, though this effect was only significant under random and fixed effects estimation, while land of higher quality raises output, though the latter coefficient was only statistically significant with the fixed effects specification. Femaleheaded households have lower outputs levels compared to their male counterparts, though the coefficient is not statistically significant in the fixed-effects estimation. This probably reflects higher variation between households then within households, which is expected, as it is unlikely that many households would change heads within the 5 -year interval. Years of farm experience contributed positively to raising output and are significant at the 10 percent level or below across each specification. Under pooled and random effects, the coefficient on household head's education attainment beyond some upper secondary schooling generally rose with attainment levels, with university providing the highest returns ${ }^{36}$. Also, with weather

35 The null hypothesis test is whether the difference in coefficients are not systematic between the fixed-effects and random effects estimations. It was rejected with a chi-squared value of 160.25

36 Among the education attainment dummies, heads with some upper secondary school, completed upper secondary and having attended university are statistically significant in the pooled and random effects regressions. Despite lacking statistical significance, the similarity in outcome between vocational and lower secondary school is due to the fact that students who don't proceed with lower secondary schooling usually pursue vocation education. 
related measures, the dry season had a negative and statistically significant impact on production for all specifications.

The coefficient for family labor is significant in all specifications, though the magnitude is lower with fixed-effects. The presence of measurement error can bias variables towards zero, which is further aggravated when fixed-effects are used. To test this possibility, the fixed-effects regression is estimated with instruments for family labor. As regional differences are likely to matter in the production of crops, separate regressions are run for north and south Vietnam. Following the literature, the typical instruments that are correlated with family farm labor input are the number of household members divided into various age categories. The possible set of instruments in this study are the number of children (6 to 15 years), young male and females adults between the age of 15 and 24, adults between 25 and 64 years old and elders. Given that there is more than one instrumental variable, a test of overidentifying restrictions is conducted under the null hypothesis that the chosen instruments are orthogonal to the error term and can therefore be validly excluded from the regression.

The first stage regression and corresponding fixed effect production function for North and South Vietnam are provided in Table 5. All instruments used ${ }^{37}$ in the first stage regression are positive and significant at the one percent level. The test of overidentification for both regions strongly did not reject the null that the instruments are uncorrelated with the error terms. The fixed effect coefficient value for instrumented family labor was similar for both regions. Hired labor was excluded from the North Vietnam regression as initial tests produced negative and statistically insignificant results, which is not surprising given the limited role of hired labor in the northern regions.

The shadow wage rate or marginal revenue product of family labor for household $h$ in year $t$ is derived with expression ( 11) using the parameter estimate of family labor share in production and the predicted value of output based on the instrumented fixed-effects specification, together with the observed adult equivalent hours of annual farm work ${ }^{38}$. Table

\footnotetext{
37 The final set of instruments were the number of young male adults, the number of male and female adults between 25 and 64 years old.

38 For 503 'out-of-sample' farmers in 1993, I use the product of actual production value with the estimated coefficient for family labor share in the numerator.
} 
6 shows the ratio of the estimated shadow wages to the market daily (male) adult wages for casual agriculture labor in 1993 and 1998. At 0.2 ,The average ratio for Vietnam was very low and similar for both years, though it rose in the south in 1998. The low ratio is indicative of limited off-farm employment opportunities that results in intensive work effort on the family farm. Smaller farms will have higher labor intensity, produce more output per area, but have lower labor productivity, consistent with a lower shadow wage ${ }^{39}$. This outcome is borne in the data where the ratio of shadow to market wages rises with farm size. Though paddy prices rose over this 5 year period, which should have raise overall shadow wages, the average hours spend in own-agriculture work in adults equivalent terms increased from 3,131 to 3,463, dampening the rise in household's shadow wages.

\subsection{Response of Shadow Wages to Changes in Rice Prices}

Higher crop prices should lead to an increase in agricultural wages ${ }^{40}$ and benefit casual workers. The landless rural poor who are net suppliers of labor would gain or at least be able to mitigate the higher cost of food consumption. For this paper, I estimate the impact of higher rice prices on the shadow wage rate, which indirectly accounts for the effect of rice prices on agriculture market wages ${ }^{41}$. Family labor is the abundant factor used in the production of rice, though its factor price is unobserved.

To isolate the effect of higher paddy prices on the shadow wage rate, a reduced form regression for equation ( 11) similar to a Mincerian wage equation is used with controls added to capture demographics and household characteristics. Instead of using annual hours of family labor, $z^{H}$ which is endogenous to the household, I include instead household composition variables, using the set of instruments considered for the production function. These are expected to impact negatively on shadow wages, since the marginal product of

\footnotetext{
39 This is known as the 'inverse relationship' between farm productivity and farm size which is usually observed in developing country agriculture. As Benjamin and Brandt (2002) notes, only a few studies have econometrically estimated the degree to which the inverse relationship varies with factor market development.

${ }^{40}$ In a simple 2 factor- 2 goods framework, opening up to trade is expected to raise by even a larger percentage the factor price of a relatively abundant factor used intensively for a good in which a country has a comparative advantage as predicted by the Stolper-Samuelson theorem.

${ }^{41}$ I am currently working on estimating the impact of higher crop prices, in particular paddy prices on individual wages and will incorporate this effect into future revisions.
} 
family labor should fall, exhibiting diminishing returns with greater hours working on the farm, which is likely to be highly dependent on the household size.

The shadow wage regression takes the following log form,

$$
\ln w_{h t}^{S}=\delta_{s 0}+\sum_{i=1}^{I} \delta_{s i} \ln p_{i t}+\sum_{j=1}^{J} \ell_{j} \ln w_{j t}+\sum_{k}^{K} v_{j} \ln v_{k h t}+\sum_{m=1}^{M} \Lambda_{m} D_{m h t}+\sum_{n=1}^{N} \Theta_{n} X_{n h t}+\zeta_{h t},
$$

where $w_{h t}^{S}$ is the previously constructed adult equivalent shadow wage rate for household $h$ at time $t, p_{i t}$ is the commune price of commodity group $i$ which are paddy, other food, annuals, perennials and fruit crops, $w_{j}$ is the price of variable input for fertilizers and insecticides measured using commune level unit values, $v_{k h}$ is the quasi-fixed input, namely cultivated land and capital stock, $D_{m}$ represents demographic variables and $X_{h t}$ measures household characteristics and composition. Like the production function, separate regressions are run for North and South Vietnam to account for regional differences.

\section{Results}

Given the role of unobserved variables, the choice is between using random effects or fixed effects specification for the shadow wage regression, with the Hausman test favoring the latter. Table 7 displays fixed effect estimates for North and South Vietnam. The estimated coefficients for output prices are positive and generally statistically significant at the 10 percent level or below, with the exception of other food prices in both North and South and fruit prices in the South. Contrary to expectations, the coefficient for chemical fertilizer price is positive for both regions. Household composition variables are all negative as expected and statistically significant at the 5\% level and below. The larger the household size, the greater the annual hours of farm work - the lower the marginal product of labor and hence the shadow wage.

Focusing on paddy prices, the coefficient for North Vietnam which measures the elasticity of shadow wages with respect to paddy price, $\delta_{s r}$ is positive and highly significant whereas in the south, the coefficient is negative and not significant. This supports the intuition 
that higher paddy price raises the demand for family labor, and therefore increases their shadow wage $e^{42}$. As the impact of change in paddy price was statistically insignificant in the south, I will only utilize the elasticity of shadow wages with respect to paddy price for the north when calculating the impact of higher paddy prices on profitability.

\subsection{Farmer's Profitability}

In this section, the impact of changes in paddy and chemical fertilizer prices on farmer's shadow profits is derived. The overall rise in real paddy price and decrease in real chemical fertilizer price are expected to lift farm profits, though the indirect impact of higher paddy prices on shadow wages will dampen the increase.

Turning to second column of Table 1, real producer paddy price across Vietnam increased on average by 33.4 percent over this period. The largest rise of 42.2 percent was in the Central Highlands, where rice growing is relatively more commercialized and the lowest increase of 17.7 percent was in the Northern Uplands region, where rice is planted mainly for subsistence.

Table 8 provides the percentage change in real farm profits computed using equation with (17) using 3 scenarios, to highlight the relative importance of the paddy price, shadow wage and fertilizer price change effects. The first scenario looking at profit changes in response to paddy price holding constant shadow wages and chemical fertilizer price. The second incorporates the indirect effect of shadow wages on profitability holding fertilizer price fixed and the third looks at the full effect of rice and chemical fertilizer price changes, including the endogenous impact through the shadow wage response.

Under the first scenario, farm profits rose on average by 61.4 percent for Vietnam as a result of rising paddy prices between 1993 and 1998, holding all other variables constant.

\footnotetext{
${ }^{42}$ It is possible that the limited presence of hired labor in the North, allowed a greater role for the effect of higher labor demand in response to rising paddy prices to raise the shadow wage rate for family labor. In the South however, the response of market wages to increased paddy prices, may have raised the hours for family labor input as farms substituted away from more expensive hired labor, thereby lowering the marginal product of labor. The negative coefficient implies that this effect outweighed the positive impact of rising paddy prices on farm labor demand, causing a net decline in shadow wages.
} 
Incorporating the effects of shadow wages in the second scenario reduced profitability of Northern farmers by 5.1 percentage points relative to the first scenario. Finally, the third scenario builds on the second scenario by including falling chemical fertilizer prices. Relative to the first scenario, overall farm profitability was higher by 7.6 percentage at 69 percent.

Across all three scenarios, southern farmers saw profits rising higher by nearly twice as much compared to their northern counterparts. This could be attributed to rice farming being more commercialized in the south as opposed to the predominance of subsistence farming in the north. Rural profits rose relatively far more compared to urban farmers. The percentage change in profits in general increased with farm size. Dividing by income groups, no clear pattern could be discerned, though the richest, i.e., those in the fourth income quartile saw profits rising the most by 74.5 percent when the full effect of liberalization of the rice sector and fertilizer market is considered.

Figure 2 displays a non-parametric regression of the change in real profits as a percentage of initial income (expenditure) in 1993 against (log) real per capita household expenditure in 1993. The initial level of variable shadow profits in $1993, \pi_{0}$ for each farm household is obtained after subtracting the cost of hired labor, chemical and organic fertilizers, insecticides and the implicit cost of family labor, valued at the shadow wage rate from the total value of harvest or production. The additional farm profits due to rising paddy price and declining chemical fertilizer price slightly altered the distribution of farmer's income as measured by the Gini coefficient, raising it from 0.49 to 0.52 . This lends support to Glewwe et.al (1999) finding which stated that agriculture income did not significantly contribute to the overall rise in inequality in Vietnam over the 5 -year interval ${ }^{43}$.

\footnotetext{
43 The authors find that agriculture income while representing 42 percent of total income, accounts for only 17 percent of overall income inequality. In fact income from household enterprise, accounts for nearly half of overall inequality despite forming only 12 percent of total income.
} 


\section{Overall Household Welfare and Poverty Effects of Rice Changes}

This section combines producer and consumer welfare estimates previously obtained to determine the net welfare position of Vietnamese households after liberalization of the rice sector and chemical fertilizer imports. This leads into an assessment of trade reforms on poverty rates.

As initial income, $y_{o}$ is actually measured using household total expenditure ${ }^{44}$, which excludes the value of leisure, equation (9) is modified by subtracting the value of leisure from the change in 'full' income as seen in the numerator. Restricting our attention to exogenous changes in paddy and fertilizer price, this then becomes,

$$
\frac{W G}{y_{0}}=\frac{(T-l) \Delta w^{S}\left(p_{r}, w_{c}\right)+\Delta \pi\left(p_{r}, w^{S}\left(p_{r}\right), w_{c}\right)-C V\left(p_{1 r}, p_{o r}, u_{0}\right)}{y_{0}}
$$

The results are shown in the first three columns of Table 9. The first column present overall averages for each category while the second column and third column displays averages for the poor and non-poor households respectively. Poor households are defined as those whose per capita expenditure is below the general poverty line determined by the World Bank based on the VLSS datasets ${ }^{45}$ which is set at 1,790,000 VND in January 1998 price after deflating by monthly and regional price.

For Vietnam, the process of liberalizing rice and chemical fertilizer markets over the 5 year period results in an overall increase in household welfare by 9 percent as shown in column one of Table 9. Households in northern Vietnam had their real incomes rising higher as a fraction of initial income than in the south. On a regional basis, the poorest Northern Uplands saw the greatest rise in welfare by 11.6 percent while the richest South East region experienced an increase of 1.9 percent. As anticipated, urban households who are net buyers

\footnotetext{
44 Total household expenditure is the sum of expenditure on durable and non-durable items, including imputed rent, utilities, medical and educational expenditure as calculated by the World Bank. The final value is deflated by monthly and regional price indices with January $1^{\text {st }}, 1998$ as the base year.

45 This is based on food expenditure yielding approximately 2052 calories per person per day and non-food expenditure of the third quintile of the population. See Justino and Litchfield (2003).
} 
of rice, faced a marginal drop in their real income of 1.5 percent compared to an increase in welfare experienced by rural households of 11.7 percent. Poor urban households, as seen in column two, were unable to cope with rises in rice prices compared to their rural counterparts. In fact, it is poor rural households who saw the highest improvement in welfare at 12.7 percent of initial real income.

Households headed by males saw their welfare improve by 9.9 percent while femaleheaded households still gained but at a lower rate of 6.5 percent. More conspicuously, the distribution of gains was clearly differentiated by holdings of farmland. Non-farmers saw a drop in their welfare by 3.6 percent, with the landless poor experiencing the largest decline of 6.7 percent. On the other hand, households with farm sizes over 2.5 hectares enjoyed a rise in their welfare by 17.8 percent. On the whole, the liberalization process left rural households better off, particularly its poorest, at the expense of urban households.

\section{Poverty Assessment}

Given the interest of policy makers on the impact of various liberalization efforts on poverty rates, it is instructive to examine the impact of the rice sector liberalization on poverty incidence. The last three columns of Table 9 show the effects of the liberalization on the poverty headcount ratio, defined as the fraction of the population below the World Bank general poverty line, for different categories of households. The actual poverty rate in 1993 and 1998 are provided together with the predicted rate $\left(2^{\text {nd }}\right.$ last column) after isolating the effect of agricultural trade reforms ${ }^{46}$.

For Vietnam, the change in the overall poverty rate attributed to agricultural trade liberalization improved by nearly 7 percentage points, falling from 59.7 percent to 52.7 percent, which can be compared to the 22.3 percentage point decline in observed head poverty count between 1993 and 1998. In line with the small welfare declines experienced by

\footnotetext{
46 Additional poverty measures are shown in Table 10 which includes the poverty gap ratio $\left(\mathrm{P}_{1}\right)$ and poverty severity ratio $\left(\mathrm{P}_{2}\right)$. The poverty gap which reflects the depth of poverty, declined from $19.7 \%$ to $9.5 \%$ over the 5 year period and trade reforms led to an estimated 3 percentage points fall in the poverty gap ratio.
} 
urban households, poverty rates rose slightly in the urban areas, and fell by 8.9 percent in rural $\operatorname{areas}^{47}$.

Given that reforms addressed in this paper were targeted at the agricultural sector, farmers were better off with their average poverty rate falling by 9.6 percentage points from 68.7 to 59.1 percent. This can be contrasted against the 20.5 percentage points decline in actual poverty headcount observed among farmers over the 5 year interval. Hence liberalization of the rice and fertilizer market can explain close to half of the observed fall in poverty incidence among households engaged in agricultural work over the reform period.

\section{Robustness Check}

The direct effect of trade liberalization on households is seen through price changes. The results in this paper establish that Vietnamese households experienced a real income gain of 9 percent with liberalization of the rice sector and fertilizer market with rice prices taken from commune level price questionnaires. As a check of robustness, the outcomes can be compared against those obtained with an alternative measure of rice prices, namely median unit values derived at the commune level $^{48}$ as stated in Section 3. Both consumer and producer prices measured with unit values, appropriate deflated, rose by 18.1 percent between 1993 and 1998.

Figure 3 a shows a non-parametric regression of the ratio of welfare gain to household expenditure in 1993 on per capita expenditure in 1993 for Vietnam. Results are presented using commune prices and unit values. The outcomes with both price measures are qualitatively similarly, though the magnitude is relatively larger when commune prices are utilized $^{49}$. In both cases, middle income households, which comprise the majority of

\footnotetext{
${ }^{47}$ On a regional basis, consistent with the decline in real incomes, poverty incidence fell the most in the Northern Uplands, by 9.3 percentage points, with the smallest decline in the South East. Turning to the quartile section, 13.8 and 13.5 percent of mainly rural households, located in the second and third income quartile respectively rose above the poverty line.

48 The median unit value was derived for each commune in the data by first computing unit values for each household in the commune, then extracting the median value. This was considered to be more appropriate than using the average, in mitigating the influence of outliers.

49 On average, the welfare gain for Vietnam was 1.55 percent with unit values. Tables showing compensating variation, change in farm profit and welfare gain measured using unit values are available upon request.
} 
Vietnamese households experienced positive gains in welfare. Figure $3 \mathrm{~b}$ shows that rural households across the distribution are better off with the liberalization exercise, with poorer households benefiting proportionally more as a proportion of their initial real income.

Figures 4 and 5 display contour and surface plots of the distribution of welfare gains across households measured using commune prices and unit values respectively. Both figures are similar and show that the vast majority of Vietnamese households are concentrated in the middle-income range, as indicated by the vertical bi-variate density axis. Combining this observation with those derived from Figure $3 \mathrm{a}$ and $3 \mathrm{~b}$, it can be concluded that most Vietnamese households with the exception of urban households experienced a positive gain from liberalization of the rice and fertilizer market.

\section{Overall Poverty Assessment}

Measures that evaluate changes in poverty status such as the headcount ratio depends arbitrarily on the choice of poverty lines ${ }^{50}$. Instead of relying on any particular poverty line, an alternative and more robust technique is to use what the literature terms as poverty dominance analysis. Take two distributions, $\mathrm{A}$ and B. Using a plot of cumulative distribution function, if the distribution of $\mathrm{A}$ lies below $\mathrm{B}$ over the range of relevant poverty lines, it can be concluded that the poverty headcount ratio in $\mathrm{A}$ is less than $\mathrm{B}$, that is distribution $\mathrm{A}$ exhibits poverty dominance (or first order stochastic dominance) over distribution $\mathrm{B}^{51}$.

Turning to Vietnam, figures $6 \mathrm{~A}$ and $6 \mathrm{~B}$ compare the cumulative distribution function (CDF) of predicted per-capita expenditure for panel households after the price changes against the initial per-capita expenditure in 1993 using commune price and unit values respectively. Rather than looking at the entire distribution, the distribution is shown for plausible poverty lines between 1,000,000 VND and 2,000,000 VND. For comparison, the CDF for per-capita expenditure in 1998 is also provided which clearly lies below the

\footnotetext{
50 According to Justino and Litchfield (2003), the two most common poverty line for Vietnam, are those estimated by the World Bank and the Vietnamese Ministry of Labor, Invalids and Social Affairs (MOLISA). For MOLISA, it is 750,000 VND and 1,080,000 VND in 1998 VND terms, for rural and urban households respectively.

51 See Deaton (1997) and Justino and Litchfield (2003) for discussion on poverty dominance analysis.
} 
distribution for 1993, implying an unambiguous decline in poverty levels between 1993 and 1998.

With commune prices, the CDF for the predicted expenditure lies below the CDF for initial expenditure in $1993^{52}$, though with unit values, per figure $6 \mathrm{~b}$, the predicted CDF is virtually indistinguishable from the $\mathrm{CDF}$ of the initial per-capita expenditure. Thus with commune prices, the results show that poverty did decline with liberalization of the rice sector, and this result is independent of any poverty line used.

\section{Conclusion}

This paper started out by asking how trade liberalization affects household welfare, income distribution and poverty in a developing country with a large rural economy in the presence of imperfect labor markets. Vietnam provided a unique opportunity to examine the ex-post impact of liberalization of its largest sector, i.e. rice on household well being, by virtue of a panel household survey that spanned a period of market reforms, in which agricultural trade reforms played a significant role. The lifting of rice export quotas, which by 1998 were no longer binding, contributed to increased real consumer and producer rice prices, by about 18 percent or 30 percent between 1993 and 1998, depending on the choice of price measures. Import quotas for chemical fertilizers, a key input in rice production, were also relaxed, which drove deflated prices down by 18 percent over this period.

Methodologically, this paper moves beyond the common assumption of perfect labor markets and the use of first-order responses, and instead explicitly accounts for labor market imperfections and second-order responses by producers and consumers in reacting to rice and fertilizer price changes. Estimating structural parameters of a multi-output production function enabled an assessment of the cost of household labor employed on the family farm. This was achieved by computing the shadow wage or marginal product of family adult equivalent labor. I find that rural household members are employed intensively on their farms, perhaps due to a combination of limited market opportunities and underemployment, which is

\footnotetext{
${ }^{52}$ In other word, it first-order dominates the initial per-capita distribution.
} 
reflected in very low ratios of their shadow wage to the prevailing market wage rate. The production function is also used to construct a profit function which then determines the variation in farmer's profitability in response to exogenous changes in rice and fertilizer prices while incorporating the endogenous response in the household's shadow wages to changes in rice prices.

The results point to a modest increase in average household welfare for Vietnam, though this masks clear differences between rural and urban households. The outcomes are qualitatively similar though smaller in magnitude when prices derived from unit values are used instead of those obtained from price questionnaires. This indicates that welfare estimates are sensitive to the choice of price measures, though it cannot be concluded that the use of unit values would consistently understate the magnitudes of welfare outcomes.

Rural households across the income distribution experienced an increase in their welfare, with poor rural households gaining more as a fraction of their initial real income, relative to better-off rural households. This was also reflected in the reduction of poverty incidence by 9 percentage points among rural households. By contrast, urban households saw a drop in their welfare, though marginally, with the poorest urban households being the hardest hit.

I also find that the inequality of farm income rose slightly after the respective price changes, which confirms earlier work that agriculture reforms did not aggravate overall income inequality over this period in Vietnam. Agricultural trade reforms can explain about half of the decline in poverty among farmers, who are mainly of rural origin. However, national poverty rates fell marginally with the liberalization of the rice and fertilizer market, which necessitates caution in attributing trade liberalization or more generally market reforms in the rice and fertilizer sector as contributing significantly to poverty reduction in Vietnam. Broad based economic growth between 1993 and 1998 played a prominent role in reducing poverty among households in the non-farm sector. 


\section{References:}

Arulpagasam, J., Goletti, F., Atinc, T.M and Songwe, V. (2003), "Trade in Sectors Important to the Poor: Rice in Cambodia and Vietnam and Cashmere in Mongolia", in Krumm, K. and Kharas, H. (eds) "East Asia Integrates: A Trade Policy Agenda for Shared Growth", World Bank pp. 199-220.

Benjamin, D. and Brandt, L. (2004), "Agriculture and Income Distribution in Rural Vietnam under Economic Reforms: A Tale of Two Regions", in Glewwe, P. Agrawal, N. and Dollar, D. (eds) "Economic Growth, Poverty and Household Welfare in Vietnam", World Bank, pp. 133-186.

Benjamin, D. and Brandt, (2002), "Property Rights, Labor Markets, and Efficiency in Transition Economy: The Case of Rural China", University of Toronto.

Benjamin, D. (1995), "Can unobserved land quality explain the inverse productivity relationship?", Journal of Development Economics, vol. 46, pp.51-84.

Benjamin, D. (1992), "Household Composition, Labor Markets and Labor Demand: Testing for Separation in Agricultural Household Models", Econometrica, Vol. 60(2), p. 287-322.

Deaton, A. (1997), "The Analysis of Household Surveys: A Microeconometric approach to Development Policy", John Hopkins University Press.

Deaton, A. (1989), "Rice Prices and Income Distribution in Thailand: A Non-Parametric Analysis", The Economic Journal, vol. 99 (Supplement), pp.1-37.

Deaton, A. and Zaidi, S. (2002), "Guidelines for Constructing Consumption Aggregates for Welfare Analysis", Living Standards Measurement Study Working Paper, no. 135. Washington, D.C.: World Bank.

Dollar, D. (2004), “Globalization, Inequality and Poverty since 1980”, World Bank, Policy Research Working Paper Series: 3333

Edmonds, E. and Pacvnik, N. (2002), "Does Globalization Increase Child Labor: Evidence from Vietnam”, NBER Working Paper w8670.

Glewwe, P. , Gragnolati, M. and Zaman, H. (1999), "Who gained from Vietnam's Boom in the 1990's? An Analysis of Poverty and Inequality Trends", World Bank, Policy Research Working Paper Series: 2275.

Goldberg, P. and Pavcnik, N. (2004), "Trade, Inequality, and Poverty: What Do We Know? Evidence from Recent Trade Liberalization Episodes in Developing Countries", NBER Working Paper, W10593.

Jacoby, H. (1993), "Shadow Wages and Peasant Family Labor Supply: An Econometric Application to the Peruvian Sierra", Review of Economic Studies, vol. 60(4), pp. 903-921. 
Justino, P. and Litchfield, J. (2003), "Welfare in Vietnam during the 1990s: Poverty, Inequality and Poverty Dynamics", Poverty Research Unit, University of Sussex, UK.

Justino, P. and Litchfield, J. (2002), "Poverty Dynamics in Rural Vietnam: Winners and Losers During Reform”, Poverty Research Unit, University of Sussex, UK.

Minot, N. and Goletti, F. (1997), "Impact of rice export policy on domestic prices and food security: Further analysis using the Vietnam Agricultural Spatial Equilibrium Model", International Food Policy Research Institute, Washington D.C.

Minot, N. and Goletti, F. (1998), "Export Liberalization and Household Welfare: The Case of Rice in Vietnam", American Journal of Agriculture Economics, vol. 80(4), pp.738-749

Minot, N. and Goletti, F. (2000), "Rice Market Liberalization and Poverty in Vietnam", Research Report 114, International Food Policy Research Institute, Washington D.C.

Nicita, A. (2004), "Who benefited from trade liberalization in Mexico? Measuring the effects on household welfare", World Bank Policy Research Paper 3265.

Porto, G. (2003), "Trade reforms, market access and poverty in Argentina”, World Bank Policy Research Paper 3135.

Powell, A. and Gruen, F. (1968), "The Constant Elasticity of Transformation Production Frontier and Linear Supply System", International Economic Review, vol.9, pp. 315-328.

Skoufias, E. (1994), "Using Shadow Wages to Estimate Labor Supply of Agriculture Households", American Journal of Agricultural Economics, vol. 76, pp. 215-227.

Singh, I., Squire, L and Strauss, J. (1986), "Agricultural household models: Extensions, applications, and policy", Johns Hopkins University Press for the World Bank.

Strauss, J. (1984), "Joint Determination of Food Consumption and Production in Rural Sierra Leone: Estimates of a Household-Firm Model”, Journal of Development Economics, vol.14, pp. 77103.

Ravallion, M. and Van De Walle, D. (1991), "The impact of poverty of food pricing reforms: A welfare analysis for Indonesia”, Journal of Policy Modeling, vol. 13(2), pp. 281-299.

Van De Walle, D. and Cratty, D. (2003), "Is the Emerging Non-Farm Market Economy the Route Out of Poverty in Vietnam”, World Bank Policy Research Paper, No. 2950.

Winters, L.A, McCulloch, N. and McKay, A. (2004), "Trade Liberalization and Poverty: The Evidence so Far”, Journal of Economic Literature, vol. 42(1), pp. 72-115.

Winters, L.A, (2002), “Trade Liberalization and Poverty: What are the Links?”, World Economy, vol. 25(9), pp. 1339-67. 
Table 1 Vietnam: Percentage Change in Real Prices from 1993 to 1998

\begin{tabular}{lccc} 
Household Category & $\begin{array}{c}\text { \% Chg. In } \\
\text { Consumer } \\
\text { Rice Price }\end{array}$ & $\begin{array}{c}\text { \% Chg. In } \\
\text { Producer } \\
\text { Rice Price }\end{array}$ & $\begin{array}{c}\text { \% Chg. In } \\
\text { Chemical } \\
\text { Fertilizer Price }\end{array}$ \\
\hline Vietnam & 33.4 & 31.2 & -18.3 \\
North & 27.8 & 27.0 & -20.6 \\
South & 40.1 & 36.3 & -14.6 \\
Location & & & \\
Urban & 29.2 & 24.1 & -17.9 \\
Rural & 34.4 & 32.9 & -18.3 \\
Region & & & -17.0 \\
Northern Uplands & 27.6 & 17.7 & -19.4 \\
Red River Delta & 26.0 & 28.9 & -26.6 \\
North Central Coast & 31.3 & 33.5 & -18.6 \\
South Central Coast & 42.5 & 34.8 & 0.3 \\
Central Highlands & 41.8 & 42.2 & -13.4 \\
South East & 43.9 & 36.0 & -15.5 \\
Mekong River Delta & 36.4 & 36.5 & \\
\hline
\end{tabular}

Source: Calculated from the Vietnam Living Standards Survey, 1993 and 1998

Notes:

1. Consumer and producer rice price changes are based on average prices recorded at the commune level in the VLSS community price questionnaires.

2. Fertilizer prices are average unit values calculated at the commune level.

3. There were 150 communes in 1993 . Three were not revisited in 1998 and 2 communes were split in 1998, resulting in 151 communes used for tracking changes in price. 
Table 2 Vietnam: Elasticities for Rice Supply and Demand

\begin{tabular}{|l|c|c|c|}
\hline Region & $\begin{array}{c}\text { Elasticity of } \\
\text { rice demand } \\
\text { with respect } \\
\text { to income }\end{array}$ & $\begin{array}{c}\text { Marshallian } \\
\text { Elasticity of rice } \\
\text { demand with } \\
\text { respect to rice } \\
\text { price }\end{array}$ & $\begin{array}{c}\text { Derived Hicksian } \\
\text { elasticity of rice } \\
\text { demand with } \\
\text { respect to rice } \\
\text { price }\end{array}$ \\
\hline Northern Mountain & 0.42 & -0.88 & -.074 \\
\hline Red River Delta & 0.43 & -0.92 & -.078 \\
\hline North Central Coast & 0.38 & -0.87 & -.075 \\
\hline South Central Coast & 0.20 & -0.97 & -.92 \\
\hline Central Highlands & 0.39 & -1.02 & -.89 \\
\hline South East & 0.01 & -1.12 & -1.12 \\
\hline Mekong River Delta & 0.13 & -1.01 & -0.98 \\
\hline
\end{tabular}

Sources:

Marshallian demand elasticities are from Minot and Goletti (1997) which are obtained by estimating an Almost-Ideal demand system using Vietnam Living Standard Survey 1993 data. Hicksian compensated elasticities are computed as discussed in Section 2.1.3. 
Table 3 Vietnam: Compensating Variation

\begin{tabular}{|c|c|c|}
\hline Household Category & $\begin{array}{c}\text { CV as a \% of } \\
\text { Total Exp. }\end{array}$ & $\begin{array}{c}\text { Rice Buget } \\
\text { Share (\%) }\end{array}$ \\
\hline Vietnam & 6.7 & 28.0 \\
\hline North & 7.2 & 32.9 \\
\hline South & 6.1 & 22.0 \\
\hline \multicolumn{3}{|l|}{ Location } \\
\hline Urban & 2.7 & 14.9 \\
\hline Rural & 7.7 & 31.4 \\
\hline \multicolumn{3}{|l|}{ Region } \\
\hline Northern Uplands & 5.5 & 33.7 \\
\hline Red River Delta & 7.6 & 33.0 \\
\hline North Central Coast & 8.5 & 31.9 \\
\hline South Central Coast & 6.7 & 24.6 \\
\hline Central Highlands & 10.3 & 30.9 \\
\hline South East & 4.5 & 17.0 \\
\hline Mekong River Delta & 6.0 & 22.2 \\
\hline \multicolumn{3}{|l|}{ Income group } \\
\hline $1^{\text {st }}$ quartile & 10.0 & 41.4 \\
\hline $2^{\text {nd }}$ quartile & 7.8 & 33.4 \\
\hline $3^{\text {rd }}$ quartile & 5.8 & 24.8 \\
\hline $4^{\text {th }}$ quartile & 3.1 & 12.4 \\
\hline
\end{tabular}

Notes:

1. Compensating variation is expressed as a percentage of initial household expenditure in 1993 expressed in 1998 VND after deflating by regional and monthly price indices. 
Table 4 Vietnam: CET-CD Agriculture Production Function

\begin{tabular}{|c|c|c|c|c|c|c|}
\hline \multirow[b]{2}{*}{ Log family adult male equivalent hours } & \multicolumn{2}{|c|}{ OLS-Pooled } & \multicolumn{2}{|c|}{ Random Effects } & \multicolumn{2}{|c|}{ Fixed Effects } \\
\hline & $0.075^{* * *}$ & $(0.02)$ & $0.075^{* * *}$ & $(0.01)$ & $0.049 * * *$ & $(0.02)$ \\
\hline Log hired labor hours & $0.064 * * *$ & $(0.02)$ & $0.064 * * *$ & $(0.01)$ & $0.040 * *$ & $(0.02)$ \\
\hline Log chemical fertilizer & $0.209 * * *$ & $(0.02)$ & $0.208 * * *$ & $(0.01)$ & $0.167^{* * *}$ & $(0.02)$ \\
\hline Log organic fertilizer & $0.076 * * *$ & $(0.02)$ & $0.077^{* * *}$ & $(0.01)$ & $0.101^{* * *}$ & $(0.01)$ \\
\hline Log insecticide & $0.039 * *$ & $(0.02)$ & $0.039 * * *$ & $(0.01)$ & $0.035^{* * *}$ & $(0.01)$ \\
\hline Log capital stock & $0.049 * * *$ & $(0.01)$ & $0.049 * * *$ & $(0.01)$ & $0.029 * * *$ & $(0.01)$ \\
\hline Log area cultivated & $0.398 * * *$ & $(0.05)$ & $0.398 * * *$ & $(0.01)$ & $0.378^{* * *}$ & $(0.02)$ \\
\hline Log private services value & $0.061 * * *$ & $(0.02)$ & $0.061 * * *$ & $(0.01)$ & $0.061 * * *$ & $(0.01)$ \\
\hline Log government services value & $0.049 * *$ & $(0.02)$ & $0.049 * * *$ & $(0.01)$ & $0.050 * * *$ & $(0.01)$ \\
\hline Fraction of land irrigated & -0.093 & $(0.06)$ & $-0.092 * * *$ & $(0.03)$ & -0.002 & $(0.04)$ \\
\hline fraction of poor quality land & -0.093 & $(0.06)$ & $-0.092 * * *$ & $(0.03)$ & -0.073 * & $(0.04)$ \\
\hline$\%$ poor land * $\%$ irrigated & 0.144 * & $(0.08)$ & $0.143^{* * *}$ & $(0.05)$ & 0.046 & $(0.06)$ \\
\hline fraction of good quality land & 0.131 & $(0.12)$ & 0.133 & $(0.08)$ & $0.306^{* * *}$ & $(0.10)$ \\
\hline$\%$ good land * \% irrigated & -0.120 & $(0.13)$ & -0.122 & $(0.08)$ & $-0.334 * * *$ & $(0.11)$ \\
\hline Female head & $-0.039 * *$ & $(0.02)$ & $-0.040 * *$ & $(0.02)$ & -0.051 & $(0.05)$ \\
\hline Farm experience & 0.003 * & $(0.00)$ & $0.003^{* *}$ & $(0.00)$ & $0.004^{* * *}$ & $(0.00)$ \\
\hline Farm experience squared & 0.000 & $(0.00)$ & 0.000 & $(0.00)$ & 0.000 & $(0.00)$ \\
\hline Some primary education & -0.022 & $(0.03)$ & -0.022 & $(0.02)$ & -0.002 & $(0.04)$ \\
\hline Completed primary school & 0.000 & $(0.04)$ & -0.001 & $(0.03)$ & -0.069 & $(0.05)$ \\
\hline Some lower secondary education & 0.045 & $(0.03)$ & 0.045 * & $(0.02)$ & 0.041 & $(0.04)$ \\
\hline Completed lower secondary sch. & 0.017 & $(0.03)$ & 0.016 & $(0.02)$ & -0.003 & $(0.04)$ \\
\hline Some upper secondary education & 0.067 * & $(0.04)$ & $0.067 * *$ & $(0.04)$ & 0.023 & $(0.06)$ \\
\hline Completed upper secondary sch. & 0.072 * & $(0.04)$ & $0.071 * *$ & $(0.03)$ & -0.048 & $(0.06)$ \\
\hline Attended vocational school & 0.036 & $(0.04)$ & 0.035 & $(0.03)$ & -0.079 * & $(0.05)$ \\
\hline Attended university & $0.224 * *$ & $(0.08)$ & $0.223 * * *$ & $(0.07)$ & 0.058 & $(0.12)$ \\
\hline No. of times crop loss dues to floods & 0.003 & $(0.07)$ & 0.003 & $(0.02)$ & 0.010 & $(0.02)$ \\
\hline No. of times crop loss due to pests & 0.037 & $(0.04)$ & $0.037 * *$ & $(0.01)$ & $0.030 * *$ & $(0.01)$ \\
\hline No. of times crop loss due to droughts & -0.005 & $(0.05)$ & -0.005 & $(0.01)$ & -0.004 & $(0.01)$ \\
\hline No.of times crop loss due to other factors & -0.037 & $(0.06)$ & $-0.036^{* *}$ & $(0.02)$ & -0.031 & $(0.02)$ \\
\hline dry season dummy & $-0.149 * * *$ & $(0.05)$ & $-0.149 * * *$ & $(0.02)$ & $-0.150 * * *$ & $(0.02)$ \\
\hline year dummy & 0.063 & $(0.05)$ & $0.063^{* * *}$ & $(0.02)$ & $0.081 * * *$ & $(0.02)$ \\
\hline constant & $-1.682 * * *$ & $(0.27)$ & $-1.678 * * *$ & $(0.13)$ & $-0.588 * * *$ & $(0.19)$ \\
\hline R-squared & \multicolumn{2}{|c|}{0.80} & \multicolumn{2}{|c|}{0.48} & \multicolumn{2}{|c|}{0.49} \\
\hline No. of obs/households & \multicolumn{2}{|c|}{$6410 / 3205$} & \multicolumn{2}{|c|}{$6410 / 3205$} & \multicolumn{2}{|c|}{$6410 / 3205$} \\
\hline
\end{tabular}

Notes:

1. Dependent variable is a constructed CET index of agricultural outputs at the household level using $\sigma=1.1$.

2. All regression include commune dummies and dummies for zero input values. Standard errors are in parentheses. Standard errors for the pooled estimates are corrected for clustering at the commune level. $\mathrm{R}$ squares for random and fixed effects are for within variation.

3. * indicates significance at the $10 \%$ level of confidence, ${ }^{* *}$ at the $5 \%$ level and ${ }^{* * *}$ at the $1 \%$ level of confidence. 
Table 5 North \& South Vietnam: CET-CD Agriculture Production Function (Fixed Effects-IV)

\begin{tabular}{|c|c|c|c|c|c|c|c|c|c|c|c|}
\hline \multirow[b]{3}{*}{ Log family adult equivalent hours } & \multicolumn{6}{|c|}{ North Vietnam } & \multicolumn{5}{|c|}{ South Vietnam } \\
\hline & \multicolumn{3}{|c|}{$\begin{array}{l}\text { First Stage Reg. } \\
\text { Adult Eqv. Hrs }\end{array}$} & \multicolumn{3}{|c|}{$\begin{array}{l}\text { Prod. Function } \\
\text { Fixed Effects-IV }\end{array}$} & \multicolumn{3}{|c|}{$\begin{array}{l}\text { First Stage Reg. } \\
\text { Adult Eqv. Hrs }\end{array}$} & \multicolumn{2}{|c|}{$\begin{array}{l}\text { Prod. Function } \\
\text { Fixed Effects-IV }\end{array}$} \\
\hline & - & - & - & 0.191 & $* *$ & $(0.08)$ & - & - & - & $0.193^{* *}$ & $(0.09)$ \\
\hline Log hired labor hours & - & - & - & - & - & - & 0.023 & & $(0.03)$ & $0.068 * * *$ & $(0.02)$ \\
\hline Log chemical fertilizer & 0.069 & $* * *$ & $(0.02)$ & 0.131 & $* * *$ & $(0.02)$ & 0.150 & $* * *$ & * $(0.03)$ & $0.152^{* * *}$ & $(0.03)$ \\
\hline Log organic fertilizer & 0.087 & $* * *$ & $(0.02)$ & 0.099 & & $(0.02)$ & -0.012 & & $(0.03)$ & $0.079 * * *$ & $(0.03)$ \\
\hline Log insecticide & 0.038 & $* *$ & $(0.02)$ & 0.009 & $* * *$ & $(0.02)$ & 0.022 & & $(0.03)$ & $0.067^{* * *}$ & $(0.02)$ \\
\hline Log capital stock & 0.020 & & $(0.01)$ & 0.035 & $* * *$ & $(0.01)$ & 0.025 & * & $(0.02)$ & 0.006 & $(0.01)$ \\
\hline Log area cultivated & 0.235 & $* * *$ & $(0.03)$ & 0.337 & $* * *$ & $(0.03)$ & 0.067 & $* * *$ & $(0.02)$ & $0.333^{* * *}$ & $(0.02)$ \\
\hline Log private services value & -0.056 & $* * *$ & $(0.02)$ & 0.120 & ** & $(0.02)$ & 0.001 & & $(0.03)$ & $0.059 * *$ & $(0.03)$ \\
\hline Log government services value & 0.044 & $* *$ & $(0.02)$ & 0.039 & & $(0.02)$ & 0.044 & & $(0.03)$ & $0.071 * *$ & $(0.03)$ \\
\hline Fraction of land irrigated & -0.132 & $* *$ & $(0.06)$ & 0.054 & & $(0.05)$ & 0.096 & & $(0.06)$ & 0.098 & $(0.06)$ \\
\hline fraction of poor quality land & -0.062 & & $(0.05)$ & -0.022 & & $(0.05)$ & 0.259 & $* * *$ & $(0.07)$ & -0.067 & $(0.07)$ \\
\hline$\%$ poor land * \% irrigated & 0.083 & & $(0.11)$ & -0.127 & & $(0.09)$ & -0.235 & $* *$ & $(0.11)$ & 0.121 & $(0.10)$ \\
\hline fraction of good quality land & 0.077 & & $(0.17)$ & -0.174 & & $(0.14)$ & -0.072 & & $(0.17)$ & $0.625^{* * *}$ & $(0.16)$ \\
\hline$\%$ good land * $\%$ irrigated & 0.002 & & $(0.18)$ & 0.067 & & $(0.15)$ & 0.095 & & $(0.19)$ & $-0.594^{* * *}$ & $(0.17)$ \\
\hline Female head & -0.170 & $* *$ & $(0.07)$ & 0.006 & & $(0.06)$ & -0.135 & & $(0.09)$ & -0.068 & $(0.09)$ \\
\hline Farm experience & 0.012 & $* * *$ & $(0.00)$ & 0.003 & & $(0.00)$ & 0.016 & $* * *$ & $(0.00)$ & 0.001 & $(0.00)$ \\
\hline Farm experience squared & 0.000 & $* * *$ & $(0.00)$ & 0.000 & & $(0.00)$ & 0.000 & $\star * *$ & $(0.00)$ & 0.000 & $(0.00)$ \\
\hline No. of times crop loss -floods & 0.055 & * & $(0.03)$ & 0.015 & $* * *$ & $(0.02)$ & 0.145 & $* * *$ & $(0.05)$ & -0.046 & $(0.05)$ \\
\hline No. of times crop loss - pests & 0.007 & & $(0.02)$ & 0.083 & ** & $(0.01)$ & -0.137 & $* * *$ & $(0.05)$ & $-0.196 * * *$ & $(0.05)$ \\
\hline No. of times crop loss - droughts & -0.112 & $* * *$ & $(0.02)$ & -0.048 & $* *$ & $(0.02)$ & 0.057 & $* * *$ & $(0.03)$ & $0.082 * * *$ & $(0.03)$ \\
\hline No.of times crop loss - other factors & 0.014 & & $(0.03)$ & -0.050 & $* * *$ & $(0.02)$ & 0.000 & & $(0.05)$ & 0.073 & $(0.05)$ \\
\hline dry season dummy & 0.109 & $* * *$ & $(0.02)$ & -0.277 & $* * *$ & $(0.02)$ & 0.160 & $* * *$ & $(0.04)$ & -0.017 & $(0.04)$ \\
\hline year dummy & 0.073 & $* * *$ & $(0.03)$ & 0.123 & $* * *$ & $(0.02)$ & -0.205 & $* * *$ & $(0.05)$ & 0.015 & $(0.05)$ \\
\hline No. of young males & 0.185 & $* * *$ & $(0.02)$ & - & - & - & 0.215 & $* * *$ & $(0.03)$ & - & - \\
\hline No. of male adults & 0.216 & $* * *$ & $(0.04)$ & - & - & - & 0.213 & $\star * \star$ & $(0.04)$ & - & - \\
\hline No. of female adults & 0.156 & $* * *$ & $(0.03)$ & - & - & - & 0.197 & $\star * *$ & $(0.05)$ & - & - \\
\hline R-squared & \multirow{2}{*}{\multicolumn{3}{|c|}{0.30}} & \multicolumn{3}{|c|}{0.50} & \multicolumn{3}{|c|}{0.27} & \multicolumn{2}{|l|}{0.51} \\
\hline Over-ID Test, P-value & & & & \multicolumn{3}{|c|}{0.80} & & & & \multicolumn{2}{|l|}{0.95} \\
\hline No. of obs/households & \multicolumn{3}{|c|}{$3950 / 1975$} & \multicolumn{3}{|c|}{$3950 / 1975$} & \multicolumn{3}{|c|}{$2460 / 1230$} & \multicolumn{2}{|c|}{$2460 / 1230$} \\
\hline
\end{tabular}

Notes:

1. All regression includes commune dummies and dummies for zero input values. Education attainment variables were omitted for space reasons. Standard errors are in parentheses $R$ squares are for within variation.

2. Instruments for adult equivalent labor hours are young males between ages 15 and 25, male and female adults above 25 and below 64 and elders above the age of 64 .

3. *indicates significance at the $10 \%$ level of confidence, ${ }^{* *}$ at the $5 \%$ level and ${ }^{* *}$ at the $1 \%$ level of confidence. 
Table 6: Ratio of Estimated Shadow Wage to Market Wages

Household Category

1993

1998

Vietnam

0.21

0.20

North

0.21

0.17

South

0.20

0.25

Location

Urban

0.18

0.19

Rural

0.21

0.20

Farm size (Hectares)

Less than 0.2

0.18

0.16

0.2 to 1.0

0.21

0.19

$>1.0$ to 2.5

0.24

0.33

more than 2.5

0.30

0.47

\section{Region}

Northern Uplands

0.20

0.15

Red River Delta

0.25

0.19

North Central Coast

0.17

0.15

South Central Coast

0.16

0.19

Central Highlands

0.13

0.24

South East

0.20

0.27

Mekong River Delta

0.23

0.29

Notes:

1. The shadow wage is the implicit daily wage for adult male equivalent family labor.

2. Market wage is adult male daily agricultural wage rate obtained from the VLSS community questionnaire. It is the average rates paid for planting, harvesting and clearing. 
Table 7 North \& South Vietnam: Shadow Wage Regression (Fixed Effects)

\begin{tabular}{|c|c|c|c|c|}
\hline \multirow[b]{2}{*}{ Log paddy price } & \multicolumn{2}{|c|}{$\begin{array}{c}\text { North Vietnam } \\
\text { Shadow Wage Reg. }\end{array}$} & \multicolumn{2}{|c|}{$\begin{array}{c}\text { South Vietnam } \\
\text { Shadow Wage Reg. }\end{array}$} \\
\hline & $0.418^{* * *}$ & $(0.10)$ & -0.072 & $(0.16)$ \\
\hline Log other food price & -0.032 & $(0.06)$ & 0.073 & $(0.07)$ \\
\hline Log annual crop price & 0.120 ** & $(0.05)$ & $0.160 * * *$ & $(0.06)$ \\
\hline Log perennial crop price & $0.244 * * *$ & $(0.02)$ & $0.239 * * *$ & $(0.05)$ \\
\hline Log fruit crop price & $0.225 * * *$ & $(0.05)$ & 0.038 & $(0.08)$ \\
\hline Log chemical fertilizer price & $0.179 * * *$ & $(0.07)$ & $0.312 * * *$ & $(0.12)$ \\
\hline Log organic fertilizer price & -0.002 & $(0.02)$ & 0.038 & $(0.03)$ \\
\hline Log insecticide price & 0.024 & $(0.02)$ & $0.111^{* * *}$ & $(0.04)$ \\
\hline Log area cultivated & $0.228 * * *$ & $(0.02)$ & $0.370 * * *$ & $(0.02)$ \\
\hline Log capital service & 0.012 & $(0.01)$ & 0.004 & $(0.01)$ \\
\hline Log real private services & $0.166^{* * *}$ & $(0.02)$ & $0.126 * * *$ & $(0.02)$ \\
\hline No. of infants & -0.028 & $(0.02)$ & -0.043 * & $(0.02)$ \\
\hline No. of child & $-0.047^{* * *}$ & $(0.01)$ & $-0.055^{* * *}$ & $(0.02)$ \\
\hline No. of young male adults & $-0.185 * * *$ & $(0.02)$ & $-0.188 * * *$ & $(0.03)$ \\
\hline No. of young female adults & $-0.138 * * *$ & $(0.02)$ & $-0.212 * * *$ & $(0.03)$ \\
\hline No. of male adults & $-0.151 * * *$ & $(0.03)$ & $-0.099 * *$ & $(0.04)$ \\
\hline No. of female adults & $-0.179 * * *$ & $(0.03)$ & $-0.230 * * *$ & $(0.04)$ \\
\hline Female head & $0.142 * *$ & $(0.06)$ & 0.073 & $(0.08)$ \\
\hline Farm experience & $-0.007^{* * *}$ & $(0.00)$ & $-0.012 * * *$ & $(0.00)$ \\
\hline Farm experience squared & $0.000 * *$ & $(0.00)$ & $0.000 * * *$ & $(0.00)$ \\
\hline Some primary education & -0.064 & $(0.05)$ & 0.038 & $(0.07)$ \\
\hline Completed primary school & $-0.146 * *$ & $(0.06)$ & 0.020 & $(0.09)$ \\
\hline Some lower secondary education & 0.068 & $(0.05)$ & 0.015 & $(0.08)$ \\
\hline Completed lower secondary school & -0.047 & $(0.05)$ & 0.016 & $(0.11)$ \\
\hline Some upper second education & 0.023 & $(0.07)$ & $0.492 * * *$ & $(0.15)$ \\
\hline Completed upper secondary school & -0.088 & $(0.06)$ & 0.058 & $(0.15)$ \\
\hline Attended vocational training & $-0.117 * *$ & $(0.05)$ & -0.074 & $(0.12)$ \\
\hline Attended university & -0.124 & $(0.13)$ & 0.060 & $(0.25)$ \\
\hline Fraction of land irrigated & $0.149 * * *$ & $(0.05)$ & 0.045 & $(0.06)$ \\
\hline fraction of poor quality land & 0.044 & $(0.05)$ & $-0.373^{* * *}$ & $(0.07)$ \\
\hline$\%$ poor land * \% irrigated & $-0.207^{\star *}$ & $(0.10)$ & $0.343^{* * *}$ & $(0.10)$ \\
\hline fraction of good quality land & $-0.349 * *$ & $(0.15)$ & $0.539 * * *$ & $(0.16)$ \\
\hline$\%$ good land * \% irrigated & 0.181 & $(0.16)$ & $-0.526 * * *$ & $(0.17)$ \\
\hline Dry season dummy & $-0.327^{* * *}$ & $(0.02)$ & $-0.151 * * *$ & $(0.04)$ \\
\hline No. of times crop loss - floods & 0.020 & $(0.02)$ & $-0.227^{* * *}$ & $(0.05)$ \\
\hline year dummy & 0.122 ** & $(0.07)$ & $0.334 * * *$ & $(0.08)$ \\
\hline constant & $-2.606 * * *$ & $(0.24)$ & $-3.329 * * *$ & $(0.31)$ \\
\hline R-squared & 0.37 & & 0.5 & \\
\hline No. of obs/households & $3926 / 1$ & & $2460 / 1$ & \\
\hline
\end{tabular}

Notes :

1. Dependent variable is the computed marginal revenue product of adult equivalent family labor or shadow wage.

2. Standard errors are in parentheses. $R$ square is for within variation.

3. ${ }^{*}$ indicates significance at the $10 \%$ level of confidence, ${ }^{* *}$ at the $5 \%$ level and ${ }^{* * *}$ at the $1 \%$ level of confidence. 
Table 8: Predicted Change in Real Farm Profits from 1993 to 1998

\begin{tabular}{|c|c|c|c|}
\hline \multirow[b]{2}{*}{ Household Category } & \multicolumn{3}{|c|}{ Average \% Change } \\
\hline & 1st Scenario & 2nd Scenario & 3rd Scenario \\
\hline Vietnam & 61.4 & 58.2 & 69.0 \\
\hline North & 45.2 & 40.1 & 49.1 \\
\hline South & 87.9 & 87.9 & 101.6 \\
\hline \multicolumn{4}{|l|}{ Location } \\
\hline Urban & 20.7 & 20.0 & 29.4 \\
\hline Rural & 64.0 & 60.7 & 71.5 \\
\hline \multicolumn{4}{|l|}{ Region } \\
\hline Northern Uplands & 43.7 & 38.5 & 47.4 \\
\hline Red River Delta & 45.0 & 40.1 & 47.7 \\
\hline North Central Coast & 47.3 & 41.9 & 53.1 \\
\hline South Central Coast & 112.7 & 112.7 & 128.5 \\
\hline Central Highlands & 50.3 & 50.3 & 51.1 \\
\hline South East & 105.4 & 105.4 & 119.6 \\
\hline Mekong River Delta & 74.6 & 74.6 & 89.2 \\
\hline \multicolumn{4}{|l|}{ Farm size (Hectares) } \\
\hline Less than 0.2 & 47.1 & 43.9 & 52.8 \\
\hline 0.2 to 1.0 & 66.3 & 62.8 & 74.0 \\
\hline$>1.0$ to 2.5 & 67.8 & 66.3 & 78.5 \\
\hline more than 2.5 & 66.2 & 65.9 & 79.2 \\
\hline \multicolumn{4}{|l|}{ Income group } \\
\hline 1st quartile & 61.7 & 57.5 & 67.9 \\
\hline 2nd quartile & 57.9 & 54.2 & 65.0 \\
\hline 3rd quartile & 62.8 & 60.3 & 71.2 \\
\hline 4th quartile & 64.8 & 63.4 & 74.5 \\
\hline
\end{tabular}

Notes:

1. First scenario looks at the change in paddy price alone. Second scenario incorporates the general equilibrium effect of paddy price changes on shadow wages. The third scenario builds on the second and includes the effect of chemical fertilizer price changes. Profits are expressed as a percentage of initial household expenditure in 1993 expressed in 1998 VND after deflating by regional and monthly price indices and correcting for outliers. 
Table 9 Vietnam: Welfare Effect of Trade Liberalization in Rice between 1993 and 1998

\begin{tabular}{|c|c|c|c|c|c|c|}
\hline \multirow[b]{2}{*}{ Household Category } & \multicolumn{3}{|c|}{$\%$ Change in Welfare } & \multicolumn{3}{|c|}{ Poverty Rate (\%) } \\
\hline & Average & Poor & NonPoor & 1993 & (Predicted) & 1998 \\
\hline Vietnam & 8.96 & 11.37 & 5.78 & 59.70 & 52.72 & 37.37 \\
\hline North & 10.17 & 13.10 & 4.16 & 71.07 & 62.79 & 44.33 \\
\hline South & 7.48 & 8.06 & 6.85 & 45.79 & 40.39 & 30.03 \\
\hline \multicolumn{7}{|l|}{ Location } \\
\hline Urban & -1.49 & -2.05 & -1.29 & 26.04 & 26.25 & 8.90 \\
\hline Rural & 11.68 & 12.70 & 10.10 & 68.45 & 59.60 & 44.65 \\
\hline \multicolumn{7}{|l|}{ Region } \\
\hline Northern Uplands & 11.63 & 13.32 & 5.92 & 77.11 & 67.85 & 56.38 \\
\hline Red River Delta & 9.47 & 14.08 & 3.01 & 64.42 & 55.59 & 32.64 \\
\hline North Central Coast & 9.79 & 11.31 & 5.41 & 76.49 & 70.38 & 48.09 \\
\hline South Central Coast & 10.75 & 14.62 & 7.05 & 48.96 & 42.18 & 35.21 \\
\hline Central Highlands & -1.65 & -2.73 & 0.62 & 67.80 & 66.10 & 52.40 \\
\hline South East & 1.90 & 2.84 & 1.39 & 34.96 & 32.52 & 70.62 \\
\hline Mekong River Delta & 10.02 & 8.37 & 11.18 & 47.42 & 40.61 & 36.92 \\
\hline \multicolumn{7}{|l|}{ Household Head } \\
\hline Male & 9.90 & 12.34 & 6.37 & 63.08 & 55.22 & 39.90 \\
\hline Female & 6.46 & 8.13 & 4.61 & 50.71 & 46.06 & 28.17 \\
\hline \multicolumn{7}{|l|}{ Occupation } \\
\hline NonFarmer & -3.60 & -6.70 & -2.33 & 28.95 & 30.86 & 19.46 \\
\hline Farmer & 12.62 & 13.59 & 11.15 & 68.67 & 59.09 & 48.19 \\
\hline \multicolumn{7}{|l|}{ FarmSize (Hectares) } \\
\hline Less than 0.2 & 5.36 & 7.37 & 2.95 & 68.10 & 63.80 & 36.80 \\
\hline 0.2 to 1.0 & 14.98 & 15.86 & 13.06 & 72.27 & 61.17 & 49.63 \\
\hline$>1.0$ to 2.5 & 16.33 & 15.51 & 16.88 & 55.15 & 41.23 & 35.06 \\
\hline more than 2.5 & 17.78 & 13.63 & 19.46 & 28.79 & 18.18 & 17.96 \\
\hline \multicolumn{7}{|l|}{ Overall Income group } \\
\hline 1st quartile & 11.87 & 11.87 & - & 100.00 & 99.40 & \\
\hline 2nd quartile & 10.81 & 10.68 & - & 100.00 & 86.16 & \\
\hline 3rd quartile & 9.24 & 9.87 & 8.85 & 38.78 & 25.28 & \\
\hline 4th quartile & 3.91 & - & 3.91 & 0.00 & 0.00 & \\
\hline \multicolumn{7}{|l|}{ Urban Income group } \\
\hline 1st quartile & -3.20 & -3.20 & - & 100.00 & 100.00 & \\
\hline 2nd quartile & -1.35 & -1.35 & - & 100.00 & 98.32 & \\
\hline 3rd quartile & -1.56 & -2.12 & -1.33 & 28.70 & 30.56 & \\
\hline 4th quartile & -1.28 & - & -1.28 & 0.00 & 0.00 & \\
\hline \multicolumn{7}{|l|}{ Rural Income group } \\
\hline 1st quartile & 12.82 & 12.82 & - & 100.00 & 99.36 & \\
\hline 2nd quartile & 12.20 & 12.05 & - & 100.00 & 84.77 & \\
\hline 3rd quartile & 11.71 & 11.78 & 11.65 & 41.08 & 24.08 & \\
\hline 4th quartile & 8.66 & - & 8.66 & 0.00 & 0.00 & \\
\hline
\end{tabular}

Note: The change in welfare is expressed as a percentage of initial household expenditure in 1993 expressed in 1998 VND after deflating by monthly and regional price indices and correcting for outliers. 
Table 10 Vietnam: Poverty Effect of Trade Liberalization in Rice between 1993 and 1998

\begin{tabular}{|c|c|c|c|c|c|c|c|c|c|}
\hline \multirow[b]{2}{*}{ Household Category } & \multicolumn{3}{|c|}{$\begin{array}{l}\text { Head Count }\left(P_{0}\right) \\
\%\end{array}$} & \multicolumn{3}{|c|}{$\begin{array}{c}\text { Poverty Gap }\left(\mathbf{P}_{1}\right) \\
\%\end{array}$} & \multicolumn{3}{|c|}{$\begin{array}{c}\text { Severity of Poverty }\left(P_{2}\right) \\
\%\end{array}$} \\
\hline & 1993 & Estimated & 1998 & 1993 & Estimated & 1998 & 1993 & Estimated & 1998 \\
\hline Vietnam & 59.70 & 52.72 & 37.37 & 19.68 & 16.70 & 9.54 & 8.55 & 7.06 & 3.55 \\
\hline North & 71.07 & 62.79 & 44.33 & 23.99 & 19.56 & 11.24 & 10.38 & 7.98 & 4.04 \\
\hline South & 45.79 & 40.39 & 30.03 & 14.41 & 13.21 & 7.74 & 6.31 & 5.94 & 3.04 \\
\hline \multicolumn{10}{|l|}{ Location } \\
\hline Urban & 26.04 & 26.25 & 8.90 & 6.72 & 7.14 & 1.69 & 2.53 & 2.77 & 0.50 \\
\hline Rural & 68.45 & 59.60 & 44.65 & 23.05 & 19.19 & 11.54 & 10.12 & 8.18 & 4.33 \\
\hline \multicolumn{10}{|l|}{ Region } \\
\hline Northern Uplands & 77.11 & 67.85 & 56.38 & 27.41 & 21.98 & 15.90 & 12.44 & 9.42 & 6.10 \\
\hline Red River Delta & 64.42 & 55.59 & 32.64 & 20.57 & 16.67 & 7.28 & 8.48 & 6.49 & 2.44 \\
\hline North Central Coast & 76.49 & 70.38 & 48.09 & 26.44 & 22.16 & 11.84 & 11.58 & 9.11 & 4.07 \\
\hline South Central Coast & 48.96 & 42.18 & 35.21 & 16.60 & 14.15 & 10.63 & 7.82 & 6.47 & 4.72 \\
\hline Central Highlands & 67.80 & 66.10 & 52.40 & 24.55 & 26.49 & 19.10 & 12.10 & 13.93 & 9.57 \\
\hline South East & 34.96 & 32.52 & 7.62 & 9.92 & 9.84 & 1.34 & 4.07 & 4.20 & 0.37 \\
\hline Mekong River Delta & 47.42 & 40.61 & 36.92 & 14.44 & 12.90 & 8.15 & 5.98 & 5.60 & 2.67 \\
\hline \multicolumn{10}{|l|}{ Household Head } \\
\hline Male & 63.08 & 55.22 & 39.90 & 20.84 & 17.45 & 10.26 & 9.05 & 7.36 & 3.84 \\
\hline Female & 50.71 & 46.06 & 28.17 & 16.61 & 14.71 & 6.92 & 7.21 & 6.26 & 2.52 \\
\hline \multicolumn{10}{|l|}{ Occupation } \\
\hline NonFarmer & 28.95 & 30.86 & 19.46 & 8.55 & 9.85 & 4.34 & 3.60 & 4.41 & 1.46 \\
\hline Farmer & 68.67 & 59.09 & 48.19 & 22.93 & 18.70 & 12.68 & 9.99 & 7.83 & 4.81 \\
\hline \multicolumn{10}{|l|}{ FarmSize (Hectares) } \\
\hline Less than 0.2 & 68.10 & 63.80 & 36.80 & 23.26 & 21.31 & 10.31 & 10.43 & 9.38 & 4.31 \\
\hline 0.2 to 1.0 & 72.27 & 61.17 & 49.63 & 24.27 & 18.84 & 12.83 & 10.47 & 7.56 & 4.74 \\
\hline$>1.0$ to 2.5 & 55.15 & 41.23 & 35.06 & 16.77 & 13.38 & 8.13 & 7.36 & 5.91 & 2.84 \\
\hline more than 2.5 & 28.79 & 18.18 & 17.96 & 6.51 & 5.13 & 2.18 & 2.12 & 1.71 & 0.43 \\
\hline \multicolumn{10}{|l|}{ Overall Income group } \\
\hline 1st quartile & 100.00 & 99.40 & & 51.08 & 45.47 & & 27.12 & 22.80 & \\
\hline 2nd quartile & 100.00 & 86.16 & & 25.16 & 19.31 & & 6.87 & 5.22 & \\
\hline 3rd quartile & 38.78 & 25.28 & & 2.46 & 2.01 & & 0.21 & 0.22 & \\
\hline 4th quartile & 0.00 & 0.00 & & 0.00 & 0.00 & & 0.00 & 0.00 & \\
\hline \multicolumn{10}{|l|}{ Urban Income group } \\
\hline 1st quartile & 100.00 & 100.00 & & 49.21 & 50.81 & & 25.01 & 26.73 & \\
\hline 2nd quartile & 100.00 & 98.32 & & 22.56 & 23.64 & & 5.64 & 6.37 & \\
\hline 3rd quartile & 28.70 & 30.56 & & 1.74 & 2.47 & & 0.14 & 0.28 & \\
\hline 4th quartile & 0.00 & 0.00 & & 0.00 & 0.00 & & 0.00 & 0.00 & \\
\hline \multicolumn{10}{|l|}{ Rural Income group } \\
\hline 1st quartile & 100.00 & 99.36 & & 51.20 & 45.14 & & 27.25 & 22.55 & \\
\hline 2nd quartile & 100.00 & 84.77 & & 25.46 & 18.81 & & 7.01 & 5.08 & \\
\hline 3rd quartile & 41.08 & 24.08 & & 2.63 & 1.90 & & 0.22 & 0.21 & \\
\hline 4th quartile & 0.00 & 0.00 & & 0.00 & 0.00 & & 0.00 & 0.00 & \\
\hline
\end{tabular}


Figure 1 Vietnam: Compensating variation as a percentage of real household income in 1993

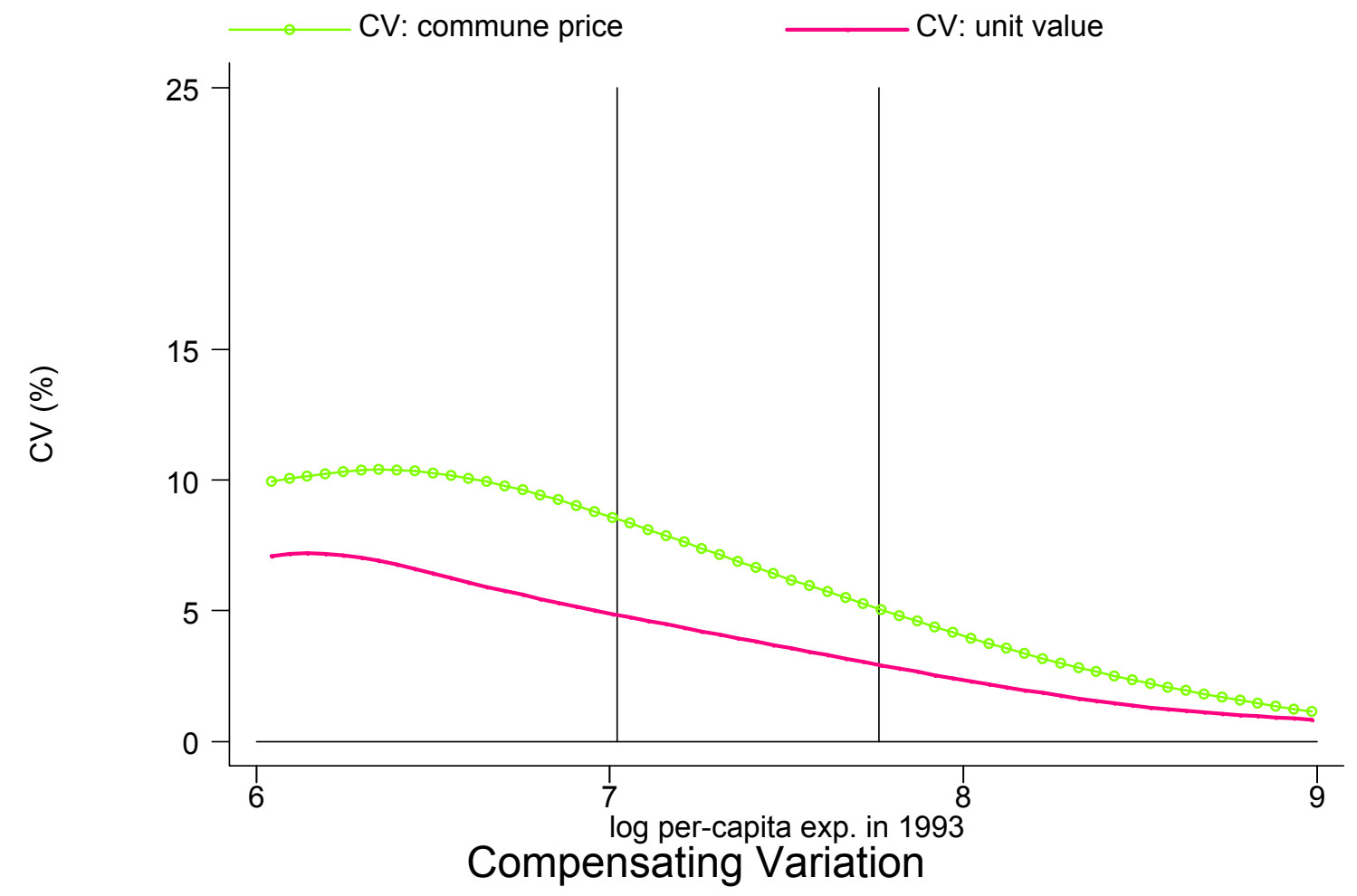

Figure 2 Vietnam: Change in farm profits as a percentage of real household income in 1993

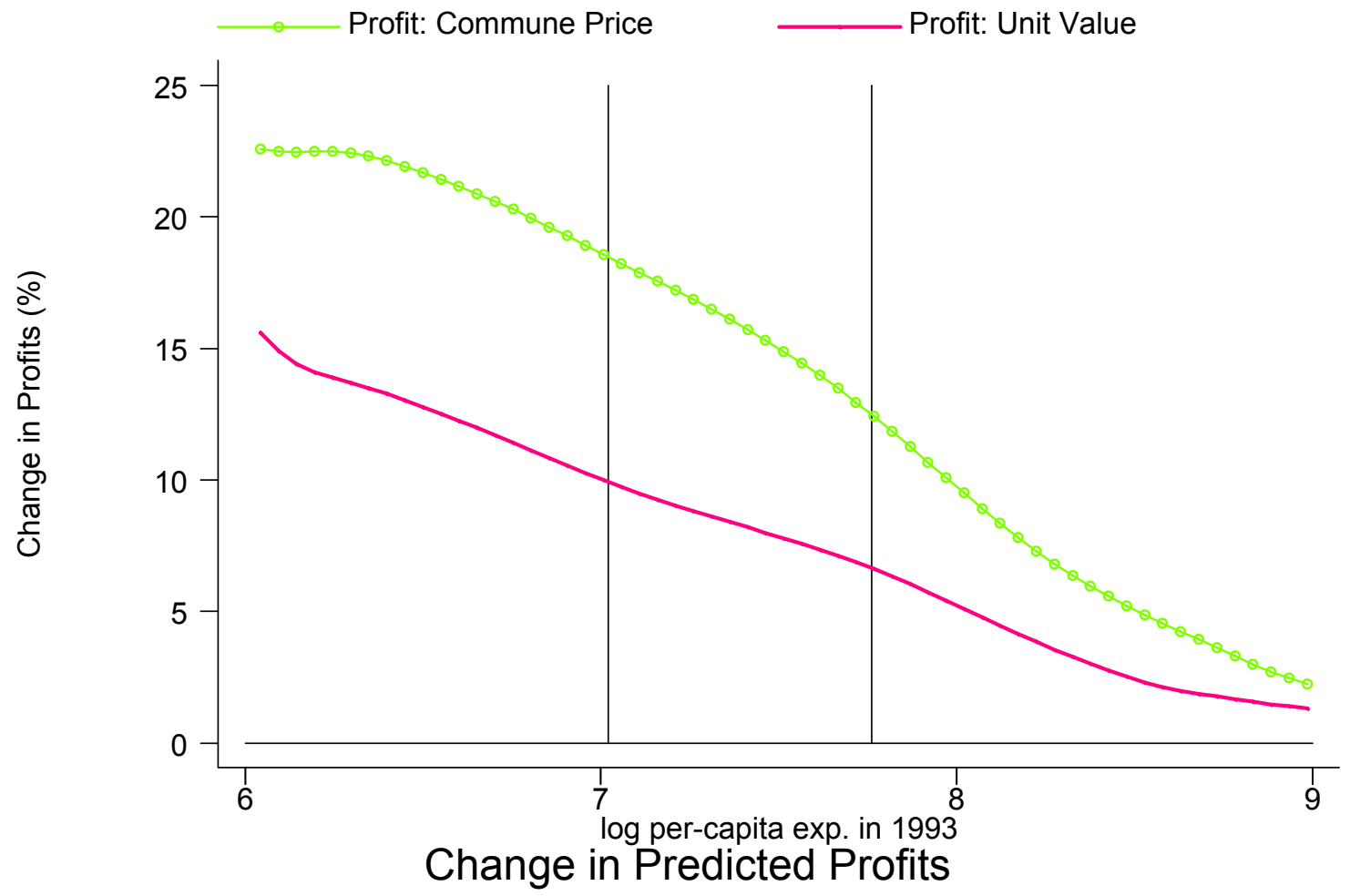


Figure 3a Vietnam: Net welfare gain as percentage of real household income in 1993

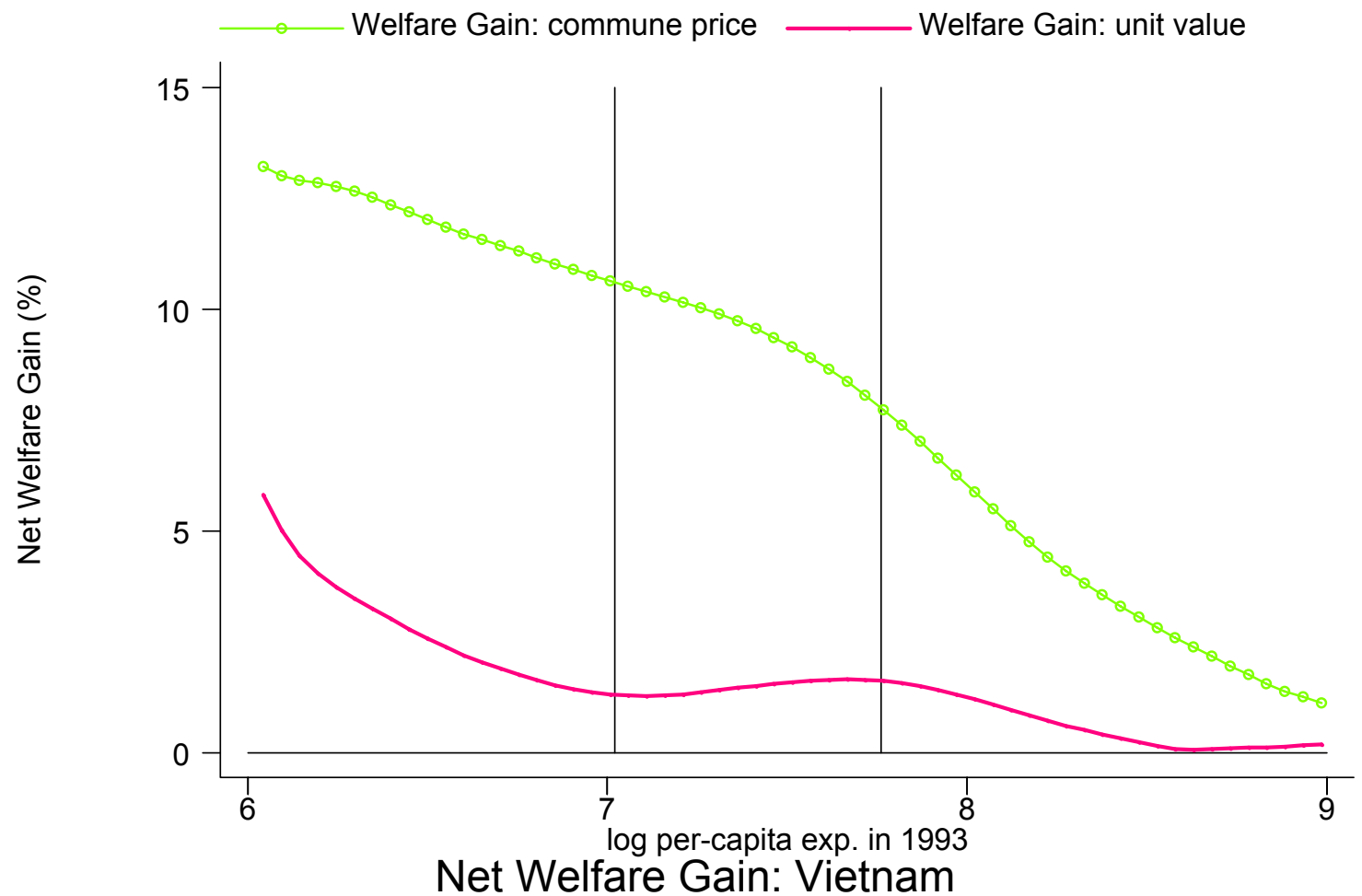

Figure 3b Rural Vietnam: Net welfare gain as percentage of real household income in 1993

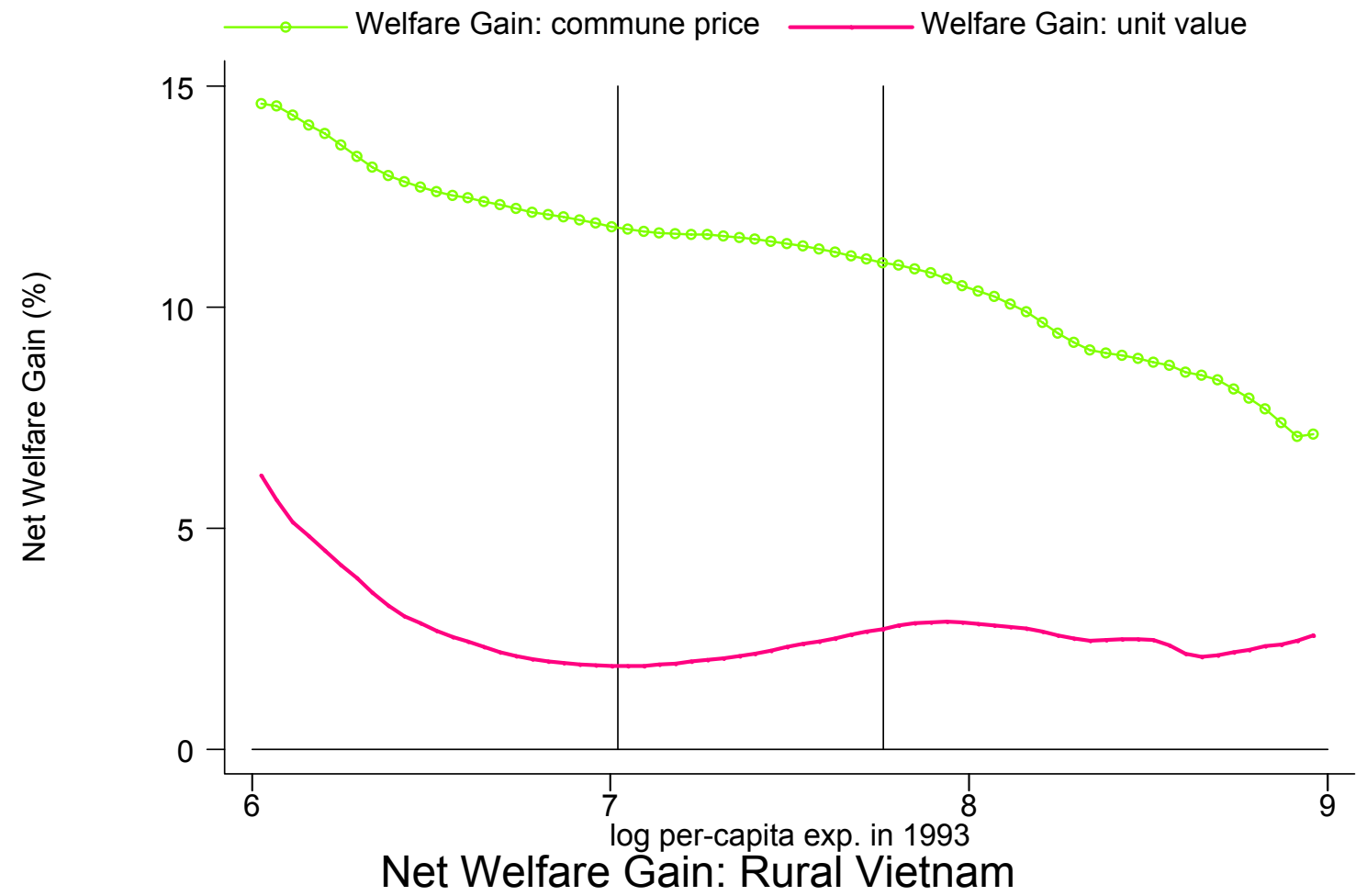


Figure 4a Vietnam: Surface plot of joint density of net welfare gain as a $\%$ of initial expenditure and log of per-capita expenditure using commune prices

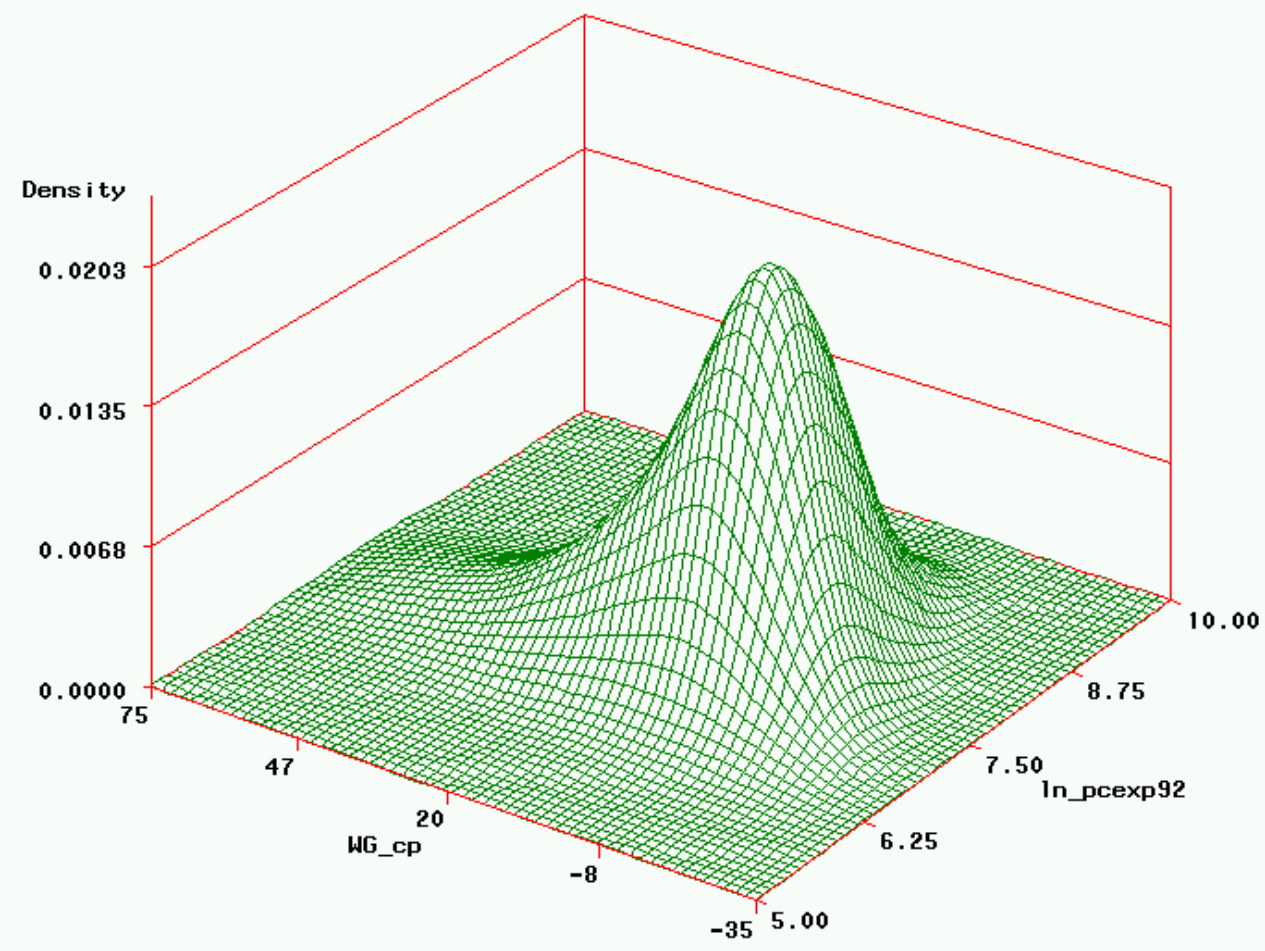

Figure 4b Vietnam: Contour plot of joint density of net welfare gain as a $\%$ of initial expenditure and log of per-capita expenditure using commune prices

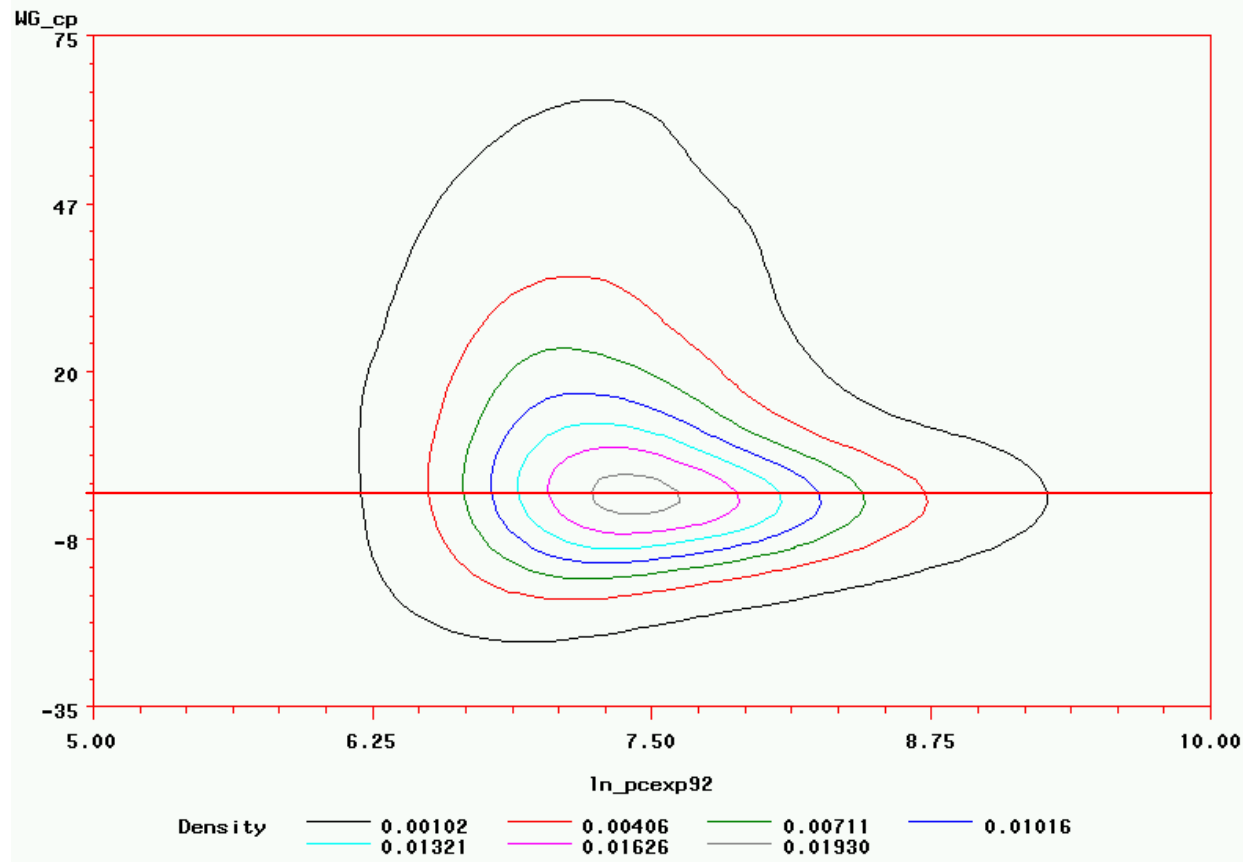


Figure 5a Vietnam: Surface plot of joint density of net welfare gain as a $\%$ of initial expenditure and log of per-capita expenditure using unit values

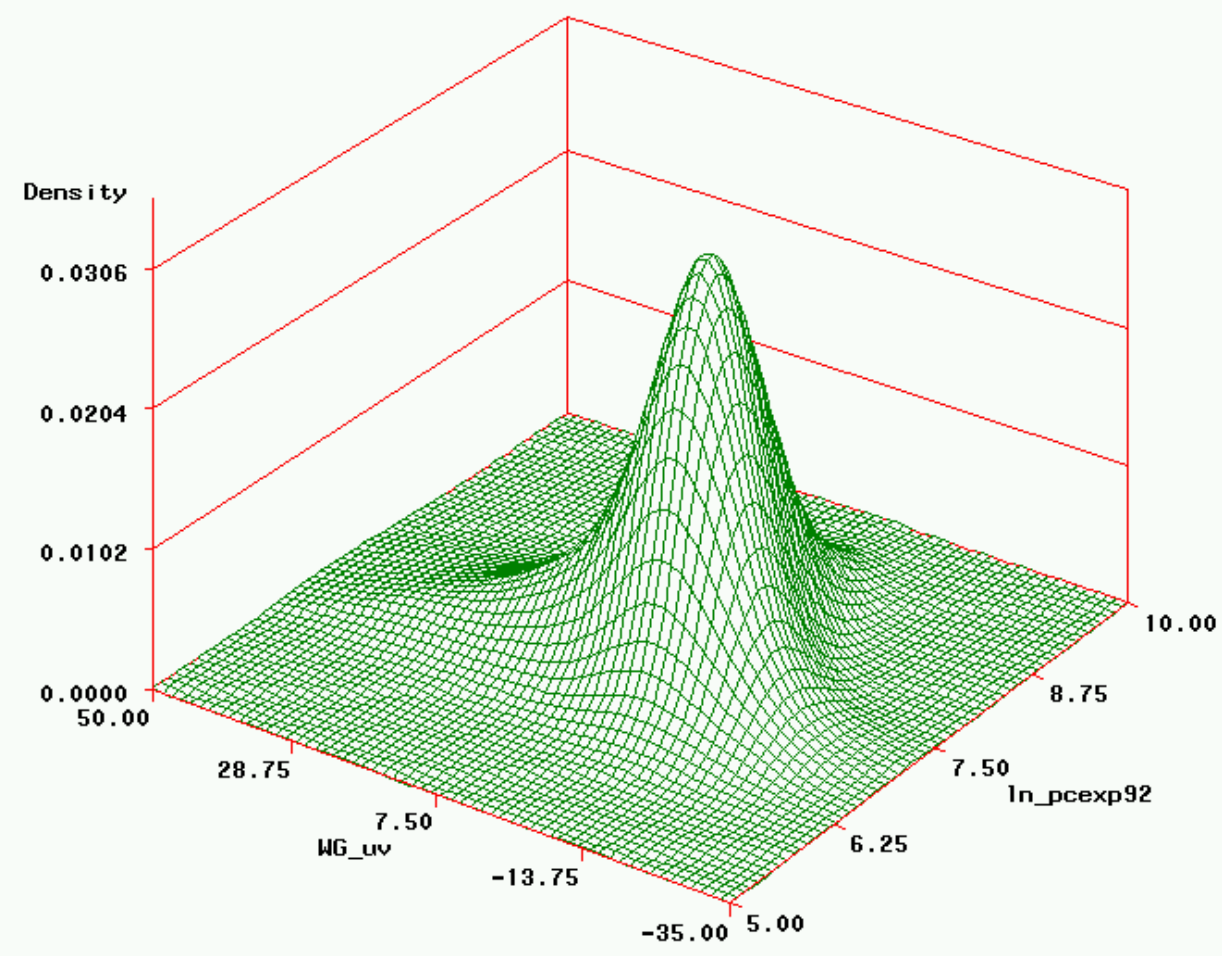

Figure 5b Vietnam: Contour plot of joint density of net welfare gain as a $\%$ of initial expenditure and log of per-capita expenditure using unit values

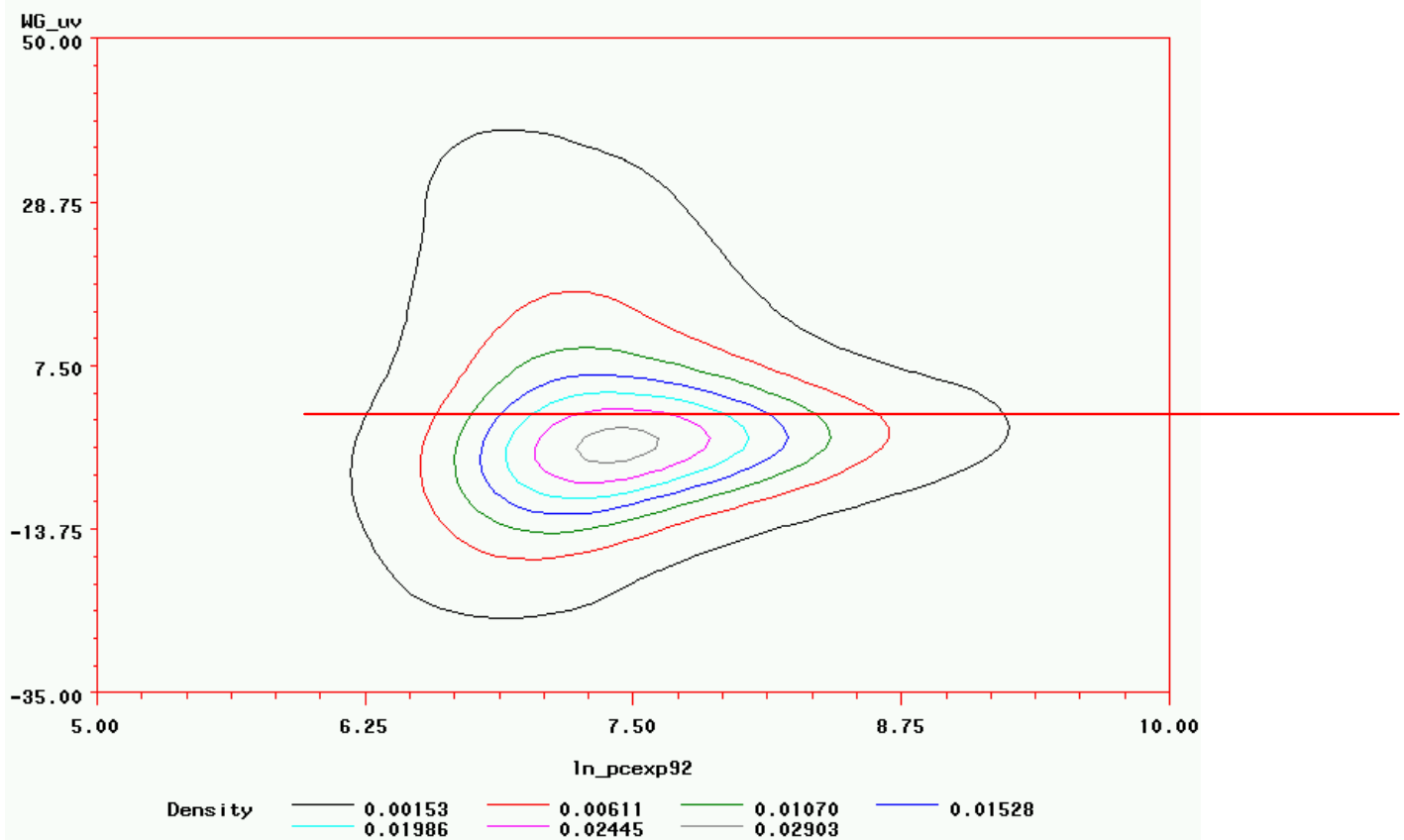


Figure 6a Vietnam: Actual and predicted distribution of real per-capita expenditure with commune prices

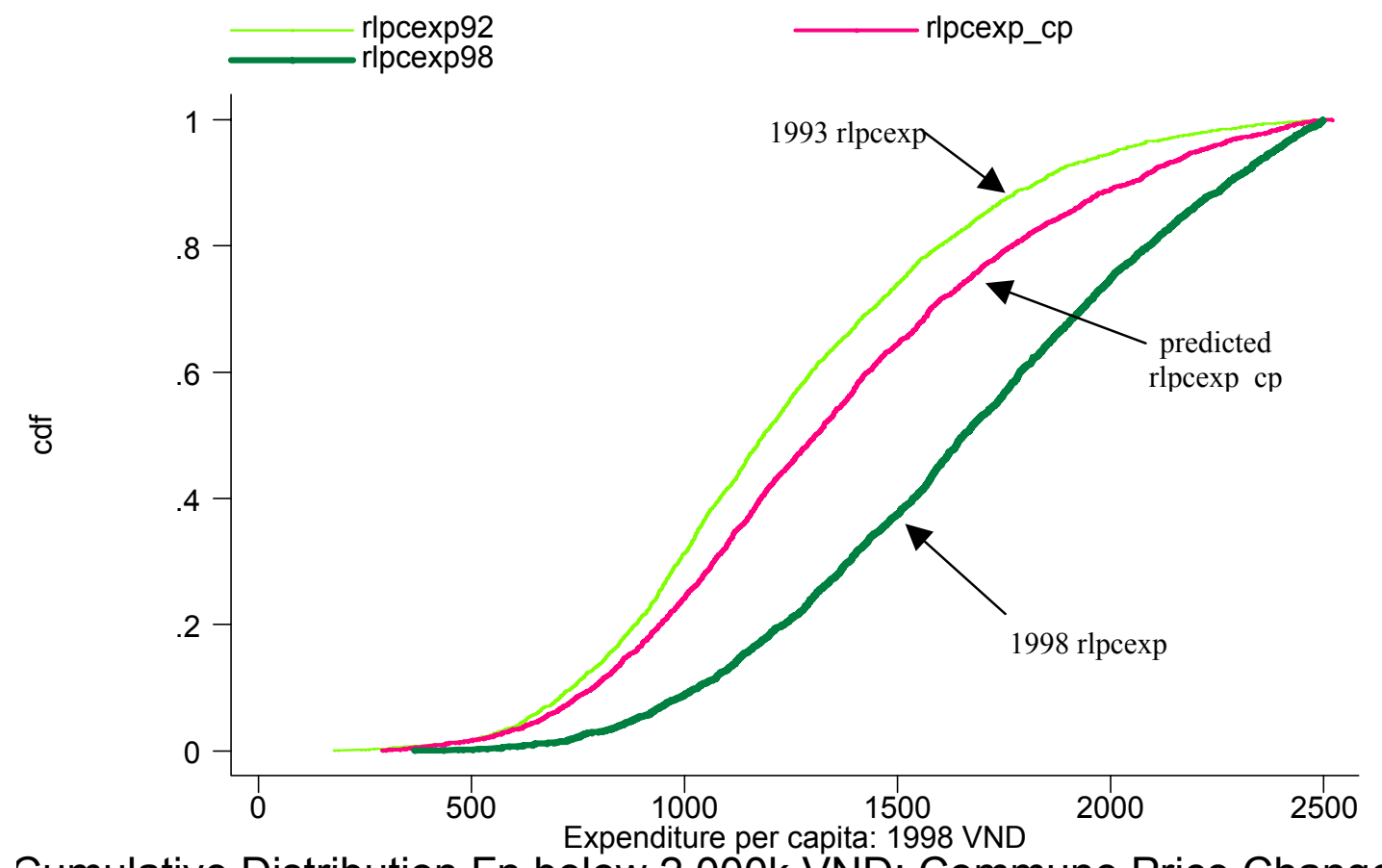

Cumulative Distribution Fn below 2,000k VND: Commune Price Change

Figure 6b Vietnam: Actual and predicted distribution of real per-capita expenditure with unit values

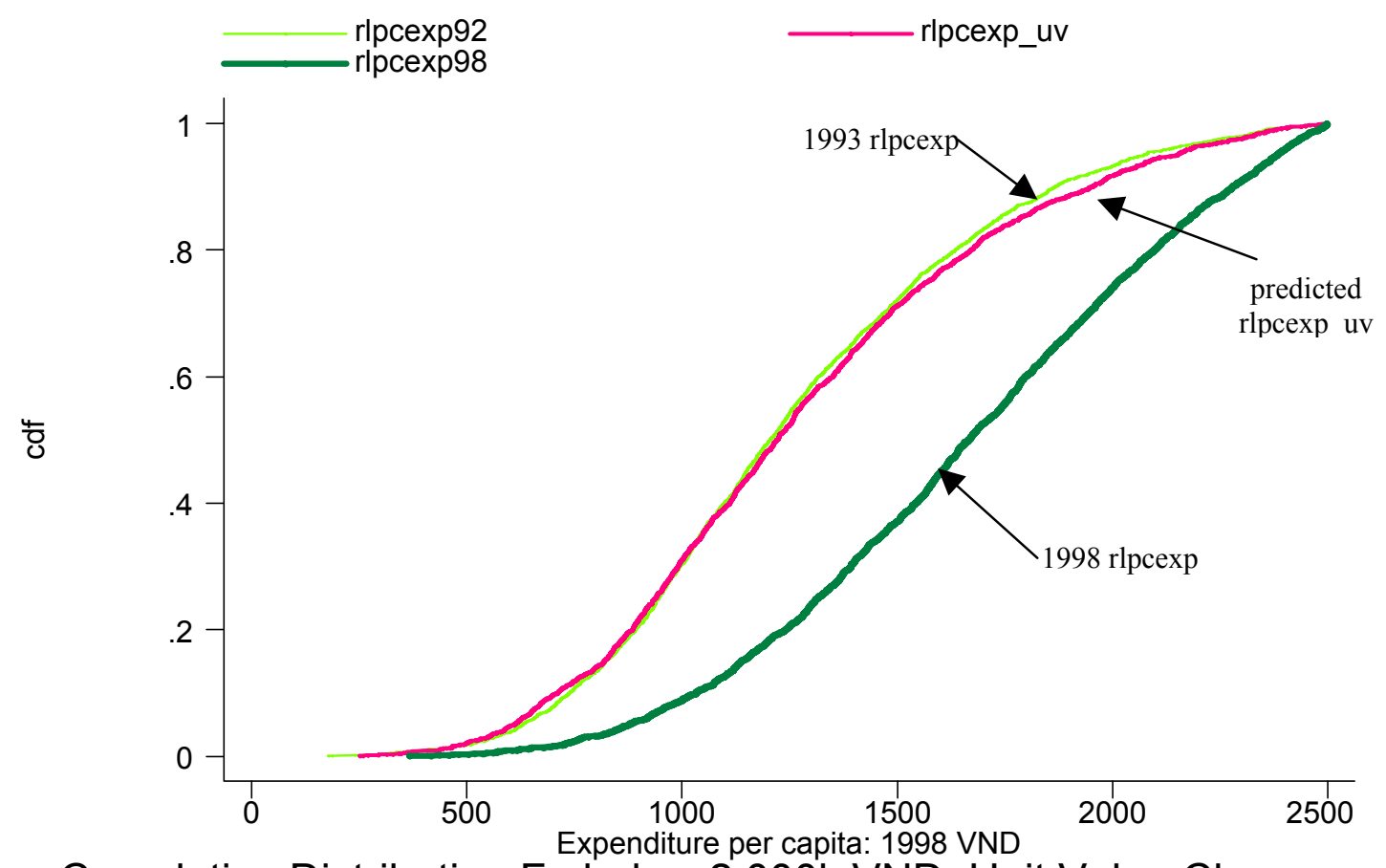

Cumulative Distribution Fn below 2,000k VND: Unit Value Change 